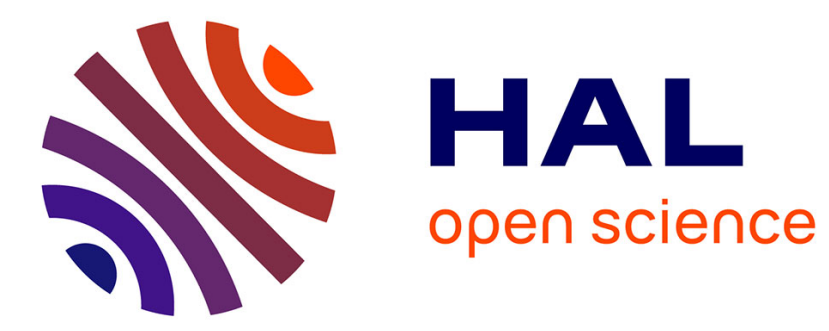

\title{
Tracking down coupled innovations supporting agroecological vegetable crop protection to foster sustainability transition of agrifood systems
}

Yann Boulestreau, Claire-Lise Peyras, Marion Casagrande, Mireille Navarrete

\section{- To cite this version:}

Yann Boulestreau, Claire-Lise Peyras, Marion Casagrande, Mireille Navarrete. Tracking down coupled innovations supporting agroecological vegetable crop protection to foster sustainability transition of agrifood systems. Agricultural Systems, 2022, 196, pp.103354. 10.1016/j.agsy.2021.103354 . hal03511140

\author{
HAL Id: hal-03511140 \\ https://hal.science/hal-03511140
}

Submitted on 4 Jan 2022

HAL is a multi-disciplinary open access archive for the deposit and dissemination of scientific research documents, whether they are published or not. The documents may come from teaching and research institutions in France or abroad, or from public or private research centers.
L'archive ouverte pluridisciplinaire HAL, est destinée au dépôt et à la diffusion de documents scientifiques de niveau recherche, publiés ou non, émanant des établissements d'enseignement et de recherche français ou étrangers, des laboratoires publics ou privés. 
2 Tracking down coupled innovations supporting agroecological

3 vegetable crop protection to foster sustainability transition of

4 agrifood systems

5

6 Yann Boulestreau ${ }^{\mathrm{a}, \mathrm{b}^{*}}$, Claire-Lise Peyras ${ }^{\mathrm{a}}$, Marion Casagrande ${ }^{\mathrm{a}, \mathrm{c}}$, Mireille Navarrete ${ }^{\mathrm{a}}$

$7 \quad{ }^{a}$ ECODEVELOPPEMENT, INRAE, 84000, Avignon, France

8 b ADEME, French Environment and Energy Management Agency 20, avenue du Grésillé- BP 90406

949004 Angers Cedex 01 France.

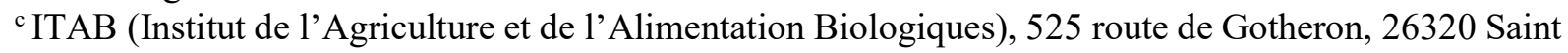
Marcel les Valence, France

* corresponding author, yann.boulestreau@tutanota.com, present address: Ziegeleistr. 11, 29585

Jelmstorf, Germany

Keywords (3-6 words): coupled innovation; sociotechnical levers; agroecology; agrifood system; niche; design

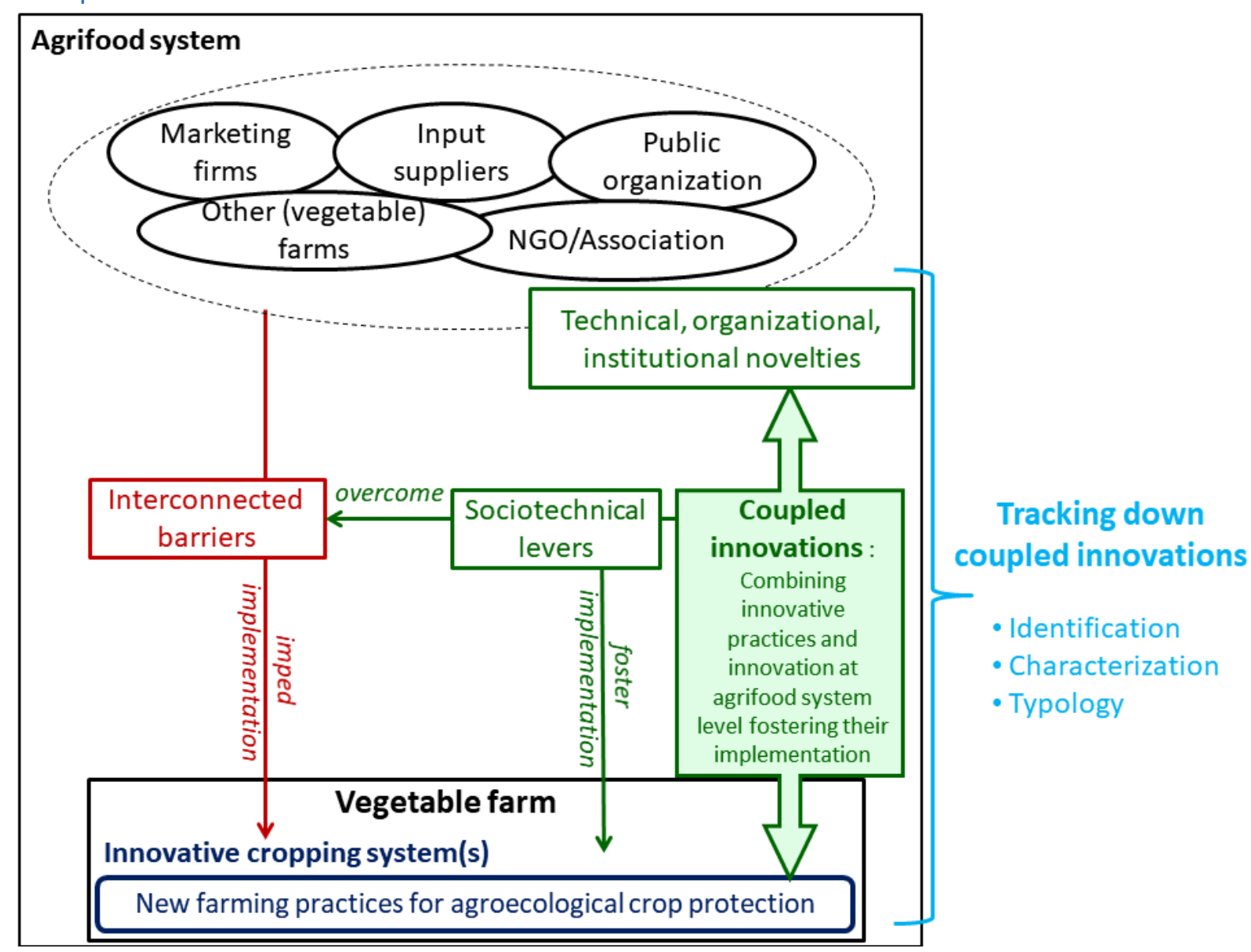




\section{Abstract}

1. CONTEXT: High pesticide use causes environmental and human health hazards. Yet, the change to alternative crop protection practices faces a web of interacting barriers that results in a sociotechnical lock-in. Designing "coupled innovation" has been proposed by agricultural scientists to overcome the barriers that prevent change in practices. Coupled innovations consist of developing jointly innovations both at the farm and the agrifood system level to overcome the lock-in.

2. OBJECTIVE: In this study, we aim at characterizing how existing coupled innovations foster the implementation of agroecological crop protection in French vegetable systems.

3. METHODS: 'Tracking down coupled innovation' method consisted of six steps: (i) identification of the existing coupled innovations in vegetable systems across France; (ii) interview of their stakeholders; (iii) identification, based on the interviews and an analytical framework, of the sociotechnical levers involved in the coupled innovations and the functions the levers perform to foster agroecological crop protection; (iv) characterization of the conditions for the coupled innovation implementation based on 20 categorical variables; (v) typology of the innovations based on the lever functions they performed, using a multiple correspondence analysis followed by hierarchical cluster analysis on principal components; (vi) comprehensive analysis of one typical innovation per cluster, to understand in-depth how it was implemented.

4. RESULTS AND CONCLUSIONS: We identified 40 coupled innovations, 17 sociotechnical lever functions and 5 consistent clusters of coupled innovations each implementing a specific combination of lever functions. The five clusters consist of: (1) co-developing and diffusing new inputs and related knowledge through specific knowledge infrastructure, (2) facilitating farmers' peer-exchange of knowledge, (3) (re)structuring the food value chain to support the implementation of agroecological crop protection, (4) pooling material and cognitive resources and (5) renting or exchanging fields to support crop diversification. Key conditions for innovation success were the support of intermediaries, a shared vision and trust between stakeholders, their active involvement, and a limited physical distance between them. The comprehensive analysis of the typical innovations illustrated, for each cluster, the complex relation between the sociotechnical levers, the functions they perform, the network involved, the ACP practices implemented and the conditions for successful implementation.

5. SIGNIFICANCE: Tracking down coupled innovation produced knowledge that can support the coupled innovation design in other contexts, hence the sustainability transition of the agrifood systems. It can complement the study of innovative farmers' practices with capitalizing knowledge on the means to overcome barriers to the implementation of these practices. 


\section{Introduction}

High pesticide use causes environmental and human health hazards (Plumecocq et al., 2018; Tilman et al., 2002). Despite public policies at the French (Ecophyto program) and at the European level (Pesticide package), pesticide use in agriculture has not significantly decreased over the last decade (Eurostat, 2021; Ministère de l'agriculture et de l'alimentation, 2020). Superior crop protection approaches do exist in terms of environmental and human health, such as Integrated Pest Management (IPM) and, more recently, Agroecological Crop Protection (ACP) (Cowan and Gunby, 1996; Deguine et al., 2016; Gamliel and van Bruggen, 2016). ACP is based on a reasoning of agroecological cropping practices which aims to "promote the ecological functioning of agroecosystems by directly or indirectly optimizing interactions between living communities (plant, animal and microbial) both in and above the ground", mainly using preventive and non-synthetic methods (Deguine et al., 2020; Wezel et al., 2014). However, scholars have recently shown that IPM and ACP were not scaling up, due to a web of interconnected barriers which lock the current agricultural systems around the conventional farming model and conventional value chains (Boulestreau et al., 2021; Cowan and Gunby, 1996; Della Rossa et al., 2020; Kernecker et al., 2021; Meynard et al., 2018; Schiller et al., 2019; Vanloqueren and Baret, 2009). For example, long-distance trade, standardization of food quality, low prices, and reliance of agricultural systems on synthetic pesticides and fertilizers are mutually reinforcing one another. (Bernard de Raymond, 2013; Boulestreau et al., 2021; Meynard et al., 2017).

Agricultural systems' scholars, based on sustainability transition studies, conceptualized the overcoming of this lock-in as a sociotechnical or sustainability transition process (Geels, 2011, 2002; Geels and Schot, 2007) towards a more sustainable agrifood system (Boulestreau et al., 2021; Klerkx and Begemann, 2020; Meynard et al., 2017; Ollivier et al., 2018; Schiller et al., 2019). An agrifood system is defined as the "system [that] gathers all the elements (environment, people, inputs, processes, infrastructure, institutions, etc.) and activities that relate to the production, processing, distribution, preparation and consumption of food and the outputs of these activities, including socioeconomic and environmental outcomes" (HLPE, 2014). The lock-in results from the very stable structuring of agrifood actors' relations over time through common rules and artifacts supported by self-reinforcing mechanisms (e.g., economies of scale) (Arthur, 1989). This stable structuration of actors, rules and artifacts called 'regime' (Geels, 2002), presents then a strong resistance to changes. Therefore this lock-in cannot be reduced to a lack of alternative techniques (hardware), but embeds social dimensions (orgware) and symbolic dimensions (software) of the technologies (Leeuwis, 2013; Rip and Kemp, 1998). In order to overcome this lock-in, networks of actors need to develop together technological, organizational and institutional innovations interlinked through different levels and 
domains of the agrifood system i.e., to design coupled innovations (Klerkx and Begemann, 2020; Meynard et al., 2017). 'Innovation' here refers to the introduction of something new (technical organizational or institutional) in an economic and social organization (Faure et al., 2018). Innovation is also contextual: something new on a territory A can be commonplace on a territory B. The term 'coupled innovation design' has been coined by Meynard et al. (2017) to conceptualize the coordinated design of innovations across cropping systems and food processing aiming to overcome the lock-in and foster change towards more sustainable practices. Salembier et al. (2020) proposed to extend this definition to the provision of inputs, including machinery, e.g., co-design of a vegetable production through a cover crop mulch and a roller-crimper, supported by an NGO. In this paper, we extend further this definition to innovations across cropping systems and any other components of the agrifood system, e.g., policies, input-provision, advisory, marketing, to tackle all the components of lock-in in agrifood systems. These innovations are often considered as necessarily developed in "innovation niches", protected from the conforming pressure of the incumbent dominant regime (Meynard et al., 2017; Pigford et al., 2018). Yet, recent literature shows that they can also arise from within the incumbent regime or at the interface of niches and regime (Belmin et al., 2018; Bui et al., 2016; Gaitán-Cremaschi et al., 2019; Morel et al., 2020). When disrupted by internal or external pressure, the dominant regime becomes unstable and opens up opportunities for the alternative innovations to scale up and take center stage within with the dominant regime, achieving the sustainability transition (Geels and Schot, 2007).

To support the agrifood system's transition, multiple studies have analyzed (i) the trajectories of change of farmer practices to gain knowledge on the barriers and levers that favor change (Chantre and Cardona, 2014; Lambrecht et al., 2014; Mawois et al., 2019; Montes de Oca Munguia et al., 2021), and (ii) entry point for innovation in the agrifood system and its agricultural innovation subsystem (Boulestreau et al., 2021; Della Rossa et al., 2020; Kernecker et al., 2021; Probst et al., 2012; Schiller et al., 2020; Schut et al., 2015; Vanloqueren and Baret, 2009). Besides, monograph analyses of innovations in agricultural contexts gave insights on how intermediaries support the innovation (Berthet et al., 2018; Kilelu et al., 2013; Kivimaa et al., 2019; Lamers et al., 2017; Leeuwis, 2013), how innovation niches emerge, and how they interact with the regime and scale-up (Belmin et al., 2018; Bui et al., 2016; Gaitán-Cremaschi et al., 2020; Klerkx et al., 2010). Yet agricultural and design studies show that providing examples of existing innovations to actors can strongly enhance their capacity to design and implement innovations adapted to their problems (Agogué et al., 2013; Girard, 2015; Klerkx et al., 2010; Périnelle et al., 2021; Salembier et al., 2020; Salembier et al., 2018). Indeed, it provides actionable knowledge both on new means to solve the problems (e.g., producing cereals with less $\mathrm{N}$ input) enhancing the creativity of the designers (Agogué et al., 2013; Salembier et al., 2016) and the 
conditions to implement them successfully (e.g., reducing pea sowing density to avoid the lodging of the cereal) (Verret et al., 2020). A 'tracking down innovative cropping systems' method was recently developed (Périnelle et al., 2021; Salembier et al., 2016; Verret et al., 2020). This approach aims to characterize a diversity of innovative farming practices or cropping systems already implemented by certain farmers, along with the underlying rationales, the conditions of their application and their outcomes, to produce resources helping the redesign of other cropping systems. It has been applied so far mainly on arable cropping systems (Périnelle et al., 2021; Salembier et al., 2016; Verret et al., 2020).

In this paper, we propose for the first time to scale up this methodology to track down coupled innovations at the agrifood system level, which support agroecological crop protection (ACP). We focus on innovations already implemented that combine innovative practices for ACP at the field level with agrifood system level innovations (technical, organizational, and/or institutional innovations) supporting the new practices. We studied 40 cases of coupled innovations within vegetable production systems in France, which are of particular interest for two reasons: (i) a strong lock-in effect has been identified around pesticide use and standard quality value chains (Bernard de Raymond, 2013; Boulestreau et al., 2021; Lefèvre et al., 2020); and (ii) consumers are highly sensitive to the issue of pesticide residues in vegetables (Baros, 2021). We hypothesize that this will yield novel and actionable knowledge on a variety of means to overcome the interconnected barriers to change towards ACP. Instead of focusing on the mechanisms involved in a few study cases, as most above-cited studies (Belmin et al., 2018; Bui et al., 2016; Gaitán-Cremaschi et al., 2020; Salembier et al., 2020; Schiller et al., 2019), we aimed to give insights into a wide variety of coupled innovations operating in different contexts. Our objective was thus twofold: (i) producing new knowledge to support the design of coupled innovation for ACP in other contexts, (ii) testing a new methodology for tracking down a large sample of coupled innovations.

\section{Materials and methods}

\subsection{Analytical framework}

We first introduce our analytical framework, presenting the concepts and tools that will support the analysis of our case studies. Considering that our case studies are sector specific (vegetable sector) and that stakeholders' interaction in agricultural systems is mainly embedded within a territory, we sought the innovations at the sectoral and territorial agrifood system (STAFS) level. The STAFS level embeds "all stakeholders from the agrifood system influencing food production, processing, distribution, preparation and consumption within the territory and the food production sector(s) in 
which the farming practices are embedded, and the interaction between these stakeholders" (Boulestreau et al., 2021).

In this study, we sought to characterize the innovative means used by agrifood system actors to overcome socio-technical interconnected barriers to ACP and the conditions for their implementation. First, in order to capture those means in our study cases, we introduce the concept of 'sociotechnical lever'. Acknowledging that interconnected barriers call for coordinated actions to overcome them, we define a "socio-technical lever" as the coordinated actions within the sociotechnical system and the functions they fulfill, which overcome a given barrier to technological change.

Applied to changes in farming practices, "sociotechnical lever" refers to the coordinated actions within the agrifood system and the function it fulfills, which modify the determinants of farming practices (Boulestreau et al., 2021) and contributes to overcoming a given barrier to change in practices towards more sustainable ones. Hence, we identified the 'sociotechnical levers' based on the determinants of the farming practices that are involved in the coupled innovations. For instance, the coordination of farmers to buy together in large volumes adequate cover crop seeds for trapping root-knot nematodes (coordinated action) change the practice determinant 'Availability of material resources' (STAFS-level, Table 1) by providing access to new input (function) to manage agroecologically this pest. Hence, it overcomes the barrier 'lack of adequate input'. We then identified the sociotechnical lever 'Access to new inputs through bulk purchase by a group of farmers'. We led this identification of the 'sociotechnical levers' based on our analytical framework of farming practice determinants at farm and STAFS level, presented Table 1. This framework was built based on insights from system agronomy, sustainability transition studies, agricultural innovation studies and rural sociology. We present it extensively in Boulestreau et al. (2021). In order to capture the conditions for the implementation and success of the innovations, we built a second part to our analytical framework (Table 2). We first built an interview guide and an initial analytical grid, aiming to collect data to understand: (i) the type of the STAFS-level innovation (technical, institutional, organizational); (ii) their relation with ACP practices (bioagressors targeted, farming practices involved); (iii) the coordination between actors (the stakeholders, the way(s) they interact); (iv) the way the coupled innovation emerged; (v) the way the coupled innovation evolved; (v) its evaluation on agronomical (impact on bioagressors), environmental (pesticide use) and social aspects (acceptability of stakeholders). Then, we made the analytical grid evolve in an abductive way by selecting qualitative variables and incumbent categories fitting both to our data and our goals. We 
Table 1 - Analytical framework of farming practice determinants at the farm and the sectoral and territorial agrifood system levels for characterizing the sociotechnical levers (adapted from Boulestreau et al., 2021).

\begin{tabular}{|c|c|c|}
\hline Level & $\begin{array}{l}\text { Categories of } \\
\text { practice } \\
\text { determinants }\end{array}$ & Examples of practice determinants \\
\hline \multirow[t]{5}{*}{ Farm level } & $\begin{array}{l}\text { Farm biophysical } \\
\text { factors }\end{array}$ & $\begin{array}{l}\text { Biological communities within the farm, agroecological infrastructure } \\
\text { (hedgerows, fallows and grass strips, topology), pedoclimatic } \\
\text { conditions }\end{array}$ \\
\hline & $\begin{array}{l}\text { On-farm } \\
\text { availability } \\
\text { material } \\
\text { resources }\end{array}$ & $\begin{array}{l}\text { Productive resources (land, capital, workforce, agricultural inputs, } \\
\text { equipment such as tractors and tools), infrastructure such as } \\
\text { greenhouse and irrigation, buildings, social networks affiliation (e.g., } \\
\text { knowledge exchange networks, mutual assistance), commercial outlet }\end{array}$ \\
\hline & $\begin{array}{l}\text { Farmer's } \\
\text { cognitive } \\
\text { resources }\end{array}$ & Empirical and scientific knowledge, know-how, skills \\
\hline & $\begin{array}{l}\text { Strategic } \\
\text { decisions }\end{array}$ & $\begin{array}{l}\text { Choices of agricultural production, marketing channel, certification, } \\
\text { long-term productive resources (e.g., infrastructure) }\end{array}$ \\
\hline & $\begin{array}{l}\text { Farmer's } \\
\text { personality, } \\
\text { preferences and } \\
\text { objectives }\end{array}$ & $\begin{array}{l}\text { Risk-aversion, ethics, beliefs, way of life, workload management, } \\
\text { personal satisfaction, priorities and goals (e.g., maximization of } \\
\text { economic profit, environmental care) }\end{array}$ \\
\hline \multirow[t]{9}{*}{$\begin{array}{l}\text { Sectoral and } \\
\text { territorial } \\
\text { agrifood } \\
\text { system (STAFS) }\end{array}$} & $\begin{array}{l}\text { Shared regulative } \\
\text { (formal) rules }\end{array}$ & $\begin{array}{l}\text { Laws, norms and industrial standards, contracts, specifications, } \\
\text { public policies (e.g., subsidies), specifically: agriculture and food } \\
\text { regulatory framework and their proper implementation and } \\
\text { enforcement }\end{array}$ \\
\hline & $\begin{array}{l}\text { Shared } \\
\text { normative rules }\end{array}$ & $\begin{array}{l}\text { Values, norms, role expectations, customs, responsibilities, duties, } \\
\text { authority systems }\end{array}$ \\
\hline & $\begin{array}{l}\text { Shared cognitive } \\
\text { rules }\end{array}$ & Beliefs, cognitive routines, paradigms \\
\hline & $\begin{array}{l}\text { Availability of } \\
\text { material } \\
\text { resources }\end{array}$ & $\begin{array}{l}\text { Storage and processing equipment, infrastructure (e.g., roads), } \\
\text { inputs, capital, skilled workforce, functional communication and } \\
\text { financial infrastructure, time }\end{array}$ \\
\hline & $\begin{array}{l}\text { STAFS } \\
\text { biophysical } \\
\text { factors }\end{array}$ & $\begin{array}{l}\text { Landscape support for biodiversity, pest communities, topology, } \\
\text { erosion risk, watershed characteristics }\end{array}$ \\
\hline & Human factors & $\begin{array}{l}\text { Individual personalities and preferences expressed in actors' } \\
\text { relations (e.g., friendliness) }\end{array}$ \\
\hline & $\begin{array}{l}\text { Stakeholder } \\
\text { cognitive } \\
\text { resources }\end{array}$ & $\begin{array}{l}\text { Empirical and scientific knowledge (e.g., on agroecological } \\
\text { practices), know-how, skills }\end{array}$ \\
\hline & $\begin{array}{l}\text { Quality of } \\
\text { knowledge } \\
\text { infrastructure }\end{array}$ & $\begin{array}{l}\text { Research, education, extension and development infrastructure (e.g., } \\
\text { experimental networks involving farmers) }\end{array}$ \\
\hline & $\begin{array}{l}\text { Multi- } \\
\text { stakeholder } \\
\text { interactions }\end{array}$ & $\begin{array}{l}\text { (Co)development and sharing of knowledge and information; project } \\
\text { collaborations (e.g., agricultural tool sharing system); public-private } \\
\text { partnerships; networks; representative bodies (e.g., farmers' union); } \\
\text { power dynamics; purchase and sale of goods (incl. food } \\
\text { commodities) }\end{array}$ \\
\hline
\end{tabular}


Table 2 - Analytical grid of the conditions for the implementation and success of the innovations and their evaluation. These conditions and evaluation are described through the qualitative variables ( $2^{\text {nd }}$ column) and their categories ( $3^{\text {rd }}$ column), grouped according to the innovation dimension addressed $\left(1^{\text {st }}\right.$ column). These variables are used as supplementary variables in the MCA analysis of our case studies $(n=40)$. The $4^{\text {th }}$ column presents, for each theme, examples of the questions we used to collect the corresponding data.

\begin{tabular}{|c|c|c|c|}
\hline $\begin{array}{l}\text { Innovation } \\
\text { dimension }\end{array}$ & Analytical variables & Categories of the variables & Examples of questions asked during the interviews \\
\hline \multirow{3}{*}{$\begin{array}{l}\text { Type of } \\
\text { innovation at } \\
\text { STAFS level }\end{array}$} & Institutional innovation & yes; no & \multirow{3}{*}{$\begin{array}{l}\text { What is the object of coordination? How does that } \\
\text { work? }\end{array}$} \\
\hline & Organizational innovation & yes; no & \\
\hline & Technical innovation & yes; no & \\
\hline \multirow{4}{*}{ How it starts } & Main initiator & farmer; upstream; downstream; R\&D & \multirow{4}{*}{$\begin{array}{c}\text { How did you set up this coordination? Who has } \\
\text { initiated it? What were the motives and interests of } \\
\text { the stakeholders? What were the stakeholders' } \\
\text { relationships? What were the conditions of success } \\
\text { for this coordination? }\end{array}$} \\
\hline & Initial motivation & $\begin{array}{l}\text { agronomic; economic; ideological; sanitary; workload; } \\
\text { multiple }\end{array}$ & \\
\hline & $\begin{array}{l}\text { Key factor of successful } \\
\text { initiation }\end{array}$ & $\begin{array}{c}\text { trust; economical support; common values; constant } \\
\text { motivation of one actor; will to gain knowledge; financial } \\
\text { equity }\end{array}$ & \\
\hline & $\begin{array}{l}\text { Stakeholders' relationship } \\
\text { before the start of the } \\
\text { innovation }\end{array}$ & professional; acquaintance; friendship & \\
\hline \multirow[b]{2}{*}{$\begin{array}{l}\text { How it is } \\
\text { implemented } \\
\text { in the long } \\
\text { term }\end{array}$} & Spatial level & municipal; production area; regional and supra-regional & \multirow[b]{2}{*}{$\begin{array}{l}\text { Who are the actors involved? How is the } \\
\text { governance organized? The mode of } \\
\text { contractualization? How do the stakeholders } \\
\text { communicate and at which frequency? }\end{array}$} \\
\hline & Stakeholder network & $\begin{array}{l}\text { farmer-farmer; farmers-R\&D; farmers-R\&D-public } \\
\text { administration; farmers-downstream; farmers-downstream- } \\
\text { R\&D-NGO; farmers-downstream-R\&D; farmers-downstream- } \\
\text { upstream; farmers-upstream-R\&D-NGO; farmers- } \\
\text { downstream-upstream-R\&D-public administration; farmers- } \\
\text { R\&D-upstream-public administration; farmers-R\&D- } \\
\text { downstream-public administration }\end{array}$ & \\
\hline
\end{tabular}




\begin{tabular}{|c|c|c|c|}
\hline & $\begin{array}{l}\text { Form of agreement between } \\
\text { stakeholders }\end{array}$ & $\begin{array}{l}\text { yearly oral agreement; optional contract; yearly contract; } \\
\text { multi-year contracts; permanent contract }\end{array}$ & \\
\hline & $\begin{array}{l}\text { Frequency of contact between } \\
\text { stakeholders }\end{array}$ & daily; weekly; several times a year; yearly & \\
\hline \multirow{4}{*}{$\begin{array}{l}\text { Relation to } \\
\text { farming } \\
\text { practices }\end{array}$} & Bioagressor targeted & $\begin{array}{c}\text { soil-borne bioagressor; aerial bioagressor; group of } \\
\text { bioagressors }\end{array}$ & \multirow{4}{*}{$\begin{array}{l}\text { Which bioagressors are targeted? Using which } \\
\text { farming practices? }\end{array}$} \\
\hline & Production system concerned & $\begin{array}{l}\text { sheltered; open-field for small-scale fresh vegetables; open- } \\
\text { field for large-scale fresh vegetables; open-field for } \\
\text { processing; multiple systems }\end{array}$ & \\
\hline & $\begin{array}{l}\text { Organic, conventional or mixed } \\
\text { stakeholders }\end{array}$ & organic; conventional; mixed & \\
\hline & $\begin{array}{l}\text { Agroecological crop protection } \\
\text { practice }(\mathrm{s}) \text { implemented }\end{array}$ & $\begin{array}{l}\text { integrated organic pest management; breaking reproduction } \\
\text { cycles; use of service crops; prophylaxis; multiple }\end{array}$ & \\
\hline \multirow{3}{*}{$\begin{array}{l}\text { Conditions of } \\
\text { success }\end{array}$} & $\begin{array}{l}\text { Main barrier(s) to successful } \\
\text { innovation }\end{array}$ & competition; lack of resources; distance; relational & \multirow{3}{*}{$\begin{array}{l}\text { How do the different stakeholders feel about this } \\
\text { innovation? What are the positive and negative } \\
\text { aspects of it? What are the barriers to this } \\
\text { coordination? What are the conditions of success } \\
\text { for this coordination? Which one is key? Which tips } \\
\text { would you give to another company to set a similar } \\
\text { coordination up? }\end{array}$} \\
\hline & Main resource(s) required & $\begin{array}{l}\text { cultivable area; common will; resource actor; outlet; } \\
\text { knowledge; inputs; capital }\end{array}$ & \\
\hline & Key factors of lasting innovation & $\begin{array}{l}\text { economic outcomes; presence of a stakeholder dedicated to } \\
\text { coordination; stakeholder flexibility; frequent solicitations; } \\
\text { unbroken trust }\end{array}$ & \\
\hline \multirow{2}{*}{ Evaluation } & $\begin{array}{l}\text { Qualitative impact on pesticide } \\
\text { use }\end{array}$ & reduction; no impact; increase; could not be evaluated & \multirow{2}{*}{$\begin{array}{l}\text { What are the impacts of this innovation? Especially } \\
\text { on the bioagressors? On the pesticide use? On the } \\
\text { stakeholders? }\end{array}$} \\
\hline & $\begin{array}{l}\text { Qualitative impact on } \\
\text { bioagressor pressure }\end{array}$ & reduction; no impact; could not be evaluated & \\
\hline
\end{tabular}




\subsection{Data collection}

201

202

203

204

205

206

207

208

209

210

211

212

213

214

215

216

217

218

219

220

221

222

223

224

225

226

227

228

229

230

231

We sought coupled innovation cases that were deemed innovative in at least one of the French vegetable production area.

The cases were selected based on the following criteria:

1. There was a clear link between ACP practices and technical, organizational and/or institutional innovations at STAFS level enabling the implementation of those practices. In some cases, enabling ACP was intended as a key goal for the stakeholders, and in others it was a spillover effect of their coordination (not intentional).

2. Each case involved at least two stakeholders from the STAFS coordinating with one another (e.g., two farmers, or a group of farmers and a marketing firm).

3. The overall sample should cover a wide range of cases, so as to identify the largest possible diversity of sociotechnical levers and conditions for implementing them. We did not strive for a representative sample at national level. To cover a wide diversity of cases, we sought to ensure that the overall sample:

a. involved all types of agrifood system stakeholders;

b. was comprised of diverse vegetable production systems: sheltered and open-field, small and large scale, production of fresh vegetables and processed vegetables;

c. related to the management of the three different types of bioagressors: pests, diseases and weeds;

d. covered all three types of innovation: institutional, organizational and technical;

e. covered different territorial scales: municipality, production area, region and beyond;

f. covered different French vegetable production areas.

In order to identify the cases and verify their novelty, we interviewed 26 R\&D experts from vegetable production systems in various French production areas and explored scientific and grey literature (Peyras, 2019). When the concept of "coupled innovation" was not clear to the interviewed expert, we provided examples based on our knowledge (e.g., specialized farmers exchanging plots to diversify). Once we had identified the cases, we presented them to the national GIS PICLég group to verify their innovative nature. The GIS PICLég is a national expert group responsible for coordinating French Research and Development (R\&D) on integrated pest management for vegetable production (www.picleg.fr). We thus selected 40 case studies (Cs) of coupled innovations (Table 3), at different stages of development: most were ongoing (31), while some were only starting (6) or had finished (3). A brief overview of the different cases is provided in the next section (2.3). 
232 For each of the 40 case studies, we led semi-structured interviews with one to four stakeholders and 233 supplemented it with the available grey literature (Table 3 ). The interviews were based on a guide with 234 questions aiming (i) to identify the sociotechnical levers (e.g., "How does the innovation work? What 235 is the role of each stakeholder? Which barrier does it overcome? How did it evolve with time?") and 236 (ii) to characterize the conditions for their implementation (see Table 2 for examples). We then selected five of the case studies for further analysis, to gain a deeper understanding of the innovations involved (Cs5, Cs23, Cs27, Cs29, Cs37, Table 3). This comprehensive analysis aimed to provide insight into the different innovation types (section 3.2.). To this end, a larger number of viewpoints were gathered (two to four interviews per case, Table 3), in order to represent the diversity of stakeholders. When information was missing, grey literature was used as a complement (Cs23, Cs27 and Cs33). The aim was to reach an understanding of the innovations as complete as possible. We should note that some of the cases involved only two stakeholders (e.g., Cs5), hence the limited number of interviews.

244 Based on the questions presented in Table 2, we deepened the interview. For example, the question 245 "How do the different stakeholders feel about this innovation?" (Table 2) was deepened with the following: "Do all stakeholders benefit from the innovation the same way?". 
Table 3 - Presentation of the 40 case studies ordered by cluster ( $1^{\text {st }}$ column) then by ascending identification number ( $2^{\text {nd }}$ column). The nature of the coupled innovations is synthesized in the $3^{\text {rd }}$ column, with linking the coordinated actions, their scale, the main stakeholders, and the farming practice concerned. The term 'local' refers to a municipal scale or a limited area of production. When a limited number of specific crops were targeted, these are indicated in brackets. The following two columns provide more information on the two parts of the coupled innovations: the type of innovation at STAFS level ( $4^{\text {th }}$ column) and the nature of the agroecological crop protection practice implemented at field and farm level (including the bioagressor targeted $-5^{\text {th }}$ column). SB=Soil borne pest(s) and/or disease(s); $A B=$ Aerial bioagressor(s). The lines in bold characters correspond to the five in-depth case studies.

\begin{tabular}{|c|c|c|c|c|c|}
\hline $\begin{array}{c}\text { Cluster } \\
n^{\circ}\end{array}$ & $\begin{array}{l}\text { Case } \\
\text { study } \\
n^{\circ}\end{array}$ & Coupled innovations & $\begin{array}{l}\text { Type of } \\
\text { innovation at } \\
\text { STAFS level }\end{array}$ & $\begin{array}{l}\text { Agroecological crop protection } \\
\text { practices implemented } \\
\text { (bioagressor targeted) }\end{array}$ & $\begin{array}{l}\text { Nb of actor } \\
\text { interviewed } \\
\text { (+ literature } \\
\text { consulted) }\end{array}$ \\
\hline 1 & 13 & $\begin{array}{l}\text { Development and evaluation at the national level of a decision-making support } \\
\text { tool for fungicide treatment for farmers by the inter-branch organization and the } \\
\text { firm supply inputs, with support for farmer use (processed beans) }\end{array}$ & Technical & Prophylaxis (SB) & $1(+1)$ \\
\hline 1 & 29 & $\begin{array}{l}\text { Coordination between farmers and R\&D for the local production and supply of } \\
\text { banker plants hosting natural enemies to fight vegetable pests }\end{array}$ & $\begin{array}{l}\text { Organizational, } \\
\text { Technical }\end{array}$ & $\begin{array}{l}\text { Organic integrated bioagressor } \\
\text { management (AB) }\end{array}$ & 4 \\
\hline 1 & 30 & $\begin{array}{l}\text { Bulk purchase of alternative vegetable crop varieties by a local group of organic } \\
\text { farmers }\end{array}$ & Organizational & $\begin{array}{l}\text { Breaking reproduction cycles by } \\
\text { crop diversification (cortege) }\end{array}$ & $1(+1)$ \\
\hline 1 & 31 & $\begin{array}{l}\text { Organization of participatory variety selection by a cooperative with a dedicated } \\
\text { experimental station and the cooperative's producers }\end{array}$ & $\begin{array}{l}\text { Organizational, } \\
\text { Technical }\end{array}$ & $\begin{array}{l}\text { Breaking reproduction cycles by } \\
\text { crop diversification (cortege) }\end{array}$ & $1(+1)$ \\
\hline 1 & 32 & $\begin{array}{l}\text { Co-development and management of an organic experimental station by local } \\
\text { stakeholders of the organic vegetable sector }\end{array}$ & Organizational & Multiple (cortege) & $1(+1)$ \\
\hline 1 & 33 & $\begin{array}{l}\text { Management of an experimental station directly by the local stakeholders of the } \\
\text { vegetable sector }\end{array}$ & Organizational & Multiple (cortege) & 2 \\
\hline 1 & 34 & $\begin{array}{l}\text { Participatory research and development on agroforestry vegetable farming } \\
\text { systems led by a private R\&D company with farmers at the national level }\end{array}$ & Organizational & Service crops (cortege) & $1(+1)$ \\
\hline 1 & 35 & $\begin{array}{l}\text { Co-development of a biocontrol system and production of natural enemies by } \\
\text { farmers and R\&D actors at the regional level }\end{array}$ & $\begin{array}{l}\text { Organizational, } \\
\text { Technical }\end{array}$ & $\begin{array}{l}\text { Organic integrated bioagressor } \\
\text { management }(A B)\end{array}$ & $1(+1)$ \\
\hline 1 & 36 & $\begin{array}{l}\text { Co-development in the Caribbean of a plant protection product made from natural } \\
\text { extract for the collective management of a problematic orphan pest (the ant } \\
\text { Acromyrmex octospinosus), by farmers and R\&D actors }\end{array}$ & $\begin{array}{l}\text { Organizational, } \\
\text { Technical }\end{array}$ & $\begin{array}{l}\text { Organic integrated bioagressor } \\
\text { management }(A B)\end{array}$ & $1(+1)$ \\
\hline
\end{tabular}




\begin{tabular}{|c|c|c|c|c|c|}
\hline 2 & 10 & $\begin{array}{l}\text { Support by public organization for land consolidation between local farmers with } \\
\text { semi-natural hedge planting }\end{array}$ & Institutional & $\begin{array}{l}\text { Organic integrated bioagressor } \\
\text { management (cortege) }\end{array}$ & 1 \\
\hline 2 & 11 & \multirow{2}{*}{$\begin{array}{l}\text { Supply by researchers of a tool for farmers, to identify, manage and map pests in } \\
\text { a participatory way, at the national level } \\
\text { Local R\&D group of organic farmers seeking to develop the practice of green } \\
\text { manure (Leek) }\end{array}$} & Technical & $\begin{array}{l}\text { Multiple, depend on the issue } \\
\text { encountered (cortege) }\end{array}$ & $1(+1)$ \\
\hline 2 & 14 & & Organizational & Service crop (weed, AB) & $1(+1)$ \\
\hline 2 & 15 & $\begin{array}{l}\text { Local R\&D group of conventional and organic farmers seeking to better manage } \\
\text { weeds in sheltered production }\end{array}$ & Organizational & $\begin{array}{l}\text { Breaking reproduction cycles by } \\
\text { mulching (weeds) }\end{array}$ & 1 \\
\hline 2 & 16 & $\begin{array}{l}\text { On-farm technical visits and peer exchange between local farmers supported by } \\
\text { an R\&D expert }\end{array}$ & Organizational & $\begin{array}{l}\text { Organic integrated bioagressor } \\
\text { management (cortege) }\end{array}$ & $1(+1)$ \\
\hline 2 & 17 & $\begin{array}{l}\text { Social media use for peer exchange and organization of meetings within a R\&D } \\
\text { group in the North of France }\end{array}$ & Technical & $\begin{array}{l}\text { Organic integrated bioagressor } \\
\text { management (cortege) }\end{array}$ & 1 \\
\hline 2 & 18 & $\begin{array}{l}\text { Social media use for peer exchange and organization of meetings within a R\&D } \\
\text { group in the East of France }\end{array}$ & Technical & $\begin{array}{l}\text { Organic integrated bioagressor } \\
\text { management (cortege) }\end{array}$ & 1 \\
\hline 2 & 20 & $\begin{array}{l}\text { Incentives for crop diversification by an organic store to its local suppliers through } \\
\text { collective crop planning supported by an extension service }\end{array}$ & Organizational & $\begin{array}{l}\text { Breaking reproduction cycles by } \\
\text { crop diversification (cortege) }\end{array}$ & 1 \\
\hline 2 & 21 & $\begin{array}{l}\text { Incentives for crop diversification by a chain of organic stores to their local } \\
\text { suppliers through collective crop planning supported by an extension service }\end{array}$ & Organizational & $\begin{array}{l}\text { Breaking reproduction cycles by } \\
\text { crop diversification (cortege) }\end{array}$ & 4 \\
\hline 2 & 23 & $\begin{array}{l}\text { Supported crop rotation design involving local organic farmers, their marketing } \\
\text { firms and R\&D actors }\end{array}$ & Organizational & $\begin{array}{l}\text { Breaking reproduction cycles } \\
\text { by crop diversification (cortege) }\end{array}$ & 2 \\
\hline 3 & 12 & $\begin{array}{l}\text { Setting up at the national level of a sustainable farming practices certification for } \\
\text { farmer organizations by farmers and the vegetable technical institute, with } \\
\text { collective penalties in case of a breach (tomato and cucumber) }\end{array}$ & Institutional & $\begin{array}{l}\text { Organic integrated bioagressor } \\
\text { management (cortege) }\end{array}$ & $1(+1)$ \\
\hline 3 & 19 & $\begin{array}{l}\text { Incentives for crop diversification by the organic cooperative to its local suppliers } \\
\text { through the shared requirement specifications }\end{array}$ & Institutional & $\begin{array}{l}\text { Breaking reproduction cycles by } \\
\text { crop diversification (cortege) }\end{array}$ & 1 \\
\hline 3 & 22 & $\begin{array}{l}\text { Incentives and technical support by an organic wholesaler for crop diversification } \\
\text { to its local suppliers }\end{array}$ & $\begin{array}{l}\text { Institutional, } \\
\text { Organizational }\end{array}$ & $\begin{array}{l}\text { Breaking reproduction cycles by } \\
\text { crop diversification (cortege) }\end{array}$ & 4 \\
\hline 3 & 24 & $\begin{array}{l}\text { Incentives for artichoke system diversification by a marketing firm to their local } \\
\text { suppliers, with the support of R\&D actors }\end{array}$ & Institutional & $\begin{array}{l}\text { Breaking reproduction cycles by } \\
\text { crop diversification (cortege) }\end{array}$ & 1 \\
\hline
\end{tabular}




\begin{tabular}{|c|c|c|c|c|c|}
\hline 3 & 37 & $\begin{array}{l}\text { Structuring at the national level of an alternative value chain around soil } \\
\text { conservation practices guaranteed by specification requirements regulating } \\
\text { stakeholders' practices and a charter, and supported by marketing firms and a } \\
\text { R\&D network }\end{array}$ & $\begin{array}{l}\text { Institutional, } \\
\text { Organizational, } \\
\text { Technical }\end{array}$ & $\begin{array}{l}\text { Organic integrated bioagressor } \\
\text { management (AB) }\end{array}$ & $4(+1)$ \\
\hline 3 & 38 & $\begin{array}{l}\text { Collective establishment of a local Halo blight-free zone for green bean seed } \\
\text { production, with prophylactic measures enforced by a dedicated multi- } \\
\text { stakeholder committee }\end{array}$ & Institutional & Prophylactic measures (SB) & $1(+1)$ \\
\hline 3 & 39 & $\begin{array}{l}\text { Support by a supermarket chain to help farmers convert to organic farming, in } \\
\text { collaboration with the inter-branch organization and chambers of agriculture at } \\
\text { the national level }\end{array}$ & $\begin{array}{l}\text { Institutional, } \\
\text { Organizational }\end{array}$ & $\begin{array}{l}\text { Organic integrated bioagressor } \\
\text { management (cortege) }\end{array}$ & 1 \\
\hline 3 & 40 & $\begin{array}{l}\text { Support for organic farmers starting out, through local institutional land release in } \\
\text { cooperation with R\&D, processing and marketing firms }\end{array}$ & $\begin{array}{l}\text { Institutional, } \\
\text { Organizational }\end{array}$ & $\begin{array}{l}\text { Organic integrated bioagressor } \\
\text { management (cortege) }\end{array}$ & 2 \\
\hline 4 & 25 & $\begin{array}{l}\text { Pooling of crop rotation, outlets, investments and workforce between two distant } \\
\text { farms increasing time availability for a better care and monitoring of the crops }\end{array}$ & Organizational & Prophylactic measures (cortege) & $2(+1)$ \\
\hline 4 & 26 & $\begin{array}{l}\text { Flexible pooling of land, workforce, equipment and sales between two local farms } \\
\text { in a polyculture system }\end{array}$ & $\begin{array}{l}\text { Institutional, } \\
\text { Organizational }\end{array}$ & $\begin{array}{l}\text { Breaking reproduction cycles by } \\
\text { crop diversification (cortege) }\end{array}$ & 2 \\
\hline 4 & 27 & $\begin{array}{l}\text { Flexible and supported pooling of land, workforce, equipment, inputs and sales } \\
\text { between four local farms fostering crop diversification and organic conversion }\end{array}$ & $\begin{array}{l}\text { Institutional, } \\
\text { Organizational }\end{array}$ & $\begin{array}{l}\text { Organic integrated bioagressor } \\
\text { management (cortege) }\end{array}$ & $2(+1)$ \\
\hline 4 & 28 & $\begin{array}{l}\text { Pooling of land management, equipment and workforce, with coordination of } \\
\text { sowing dates to prevent the rapid spread of pests and disease, between thirty-five } \\
\text { farmers across the island of Guadeloupe (melon) }\end{array}$ & $\begin{array}{l}\text { Institutional, } \\
\text { Organizational }\end{array}$ & $\begin{array}{l}\text { Organic integrated bioagressor } \\
\text { management (cortege) }\end{array}$ & 3 \\
\hline 5 & 1 & $\begin{array}{l}\text { Annual rental of open-field plots between landowners, cereal and melon farmers } \\
\text { in a large peri-urban area (melons/wheat) }\end{array}$ & Organizational & $\begin{array}{l}\text { Breaking reproduction cycles by } \\
\text { crop diversification (cortege) }\end{array}$ & $2(+1)$ \\
\hline 5 & 2 & $\begin{array}{l}\text { Annual rental of open-field plots between cereal and vegetable local farmers } \\
\text { (carrot/wheat) }\end{array}$ & Organizational & $\begin{array}{l}\text { Breaking reproduction cycles by } \\
\text { crop diversification (cortege) }\end{array}$ & 1 \\
\hline 5 & 3 & $\begin{array}{l}\text { Annual exchange of open-field plots and workforce between local farmers in a } \\
\text { context of intense pressure for land resources (celery/corn) }\end{array}$ & Organizational & $\begin{array}{l}\text { Breaking reproduction cycles by } \\
\text { crop diversification (SB) }\end{array}$ & 2 \\
\hline 5 & 4 & $\begin{array}{l}\text { Annual rental or exchange of open-field plots between local farmers (seed } \\
\text { potatoes/forage or meadow) }\end{array}$ & Organizational & $\begin{array}{l}\text { Breaking reproduction cycles by } \\
\text { crop diversification (weeds) }\end{array}$ & 1 \\
\hline
\end{tabular}




\begin{tabular}{|c|c|c|c|c|c|}
\hline 5 & 5 & Annual rental of sheltered plots between two local farmers (radish/salad) & Organizational & $\begin{array}{l}\text { Breaking reproduction cycles } \\
\text { by crop diversification (cortege) }\end{array}$ & 2 \\
\hline 5 & 6 & $\begin{array}{l}\text { Multi-year rental of an open-field plot split in three to establish a rotation between } \\
\text { two local farmers (melon/wheat) }\end{array}$ & Organizational & $\begin{array}{l}\text { Breaking reproduction cycles by } \\
\text { crop diversification (cortege) }\end{array}$ & 1 \\
\hline 5 & 7 & $\begin{array}{l}\text { Annual rental of open-field plots between a Belgian processing company and } \\
\text { French farmers or landowners (potatoes) }\end{array}$ & Organizational & $\begin{array}{l}\text { Breaking reproduction cycles by } \\
\text { crop diversification }(\mathrm{SB})\end{array}$ & 1 \\
\hline 5 & 8 & $\begin{array}{l}\text { Annual or biannual rental of open-field plots between carrot and arable local } \\
\text { farmers (carrot/maize) }\end{array}$ & $\begin{array}{l}\text { Institutional, } \\
\text { Organizational }\end{array}$ & $\begin{array}{l}\text { Breaking reproduction cycles by } \\
\text { crop diversification (SB, weeds) }\end{array}$ & 1 \\
\hline 5 & 9 & $\begin{array}{l}\text { Rental of open-field plots between two local farmers, with the one involved in a } \\
\text { technical group aiming to improve the sustainability of farming practices } \\
\text { (potatoes) }\end{array}$ & Organizational & $\begin{array}{l}\text { Breaking reproduction cycles by } \\
\text { crop diversification (SB) }\end{array}$ & 1 \\
\hline
\end{tabular}




\subsection{Brief overview of the 40 case studies}

The 40 case studies (Table 3) covered diverse territories, across eight of the twelve metropolitan French regions and two overseas regions. The cases captured a diversity of vegetable farming systems, e.g., market gardening in open-field production (10\% of the Cs), under shelter (12.5\%), large-scale open-field production of fresh vegetables (30\%), and processing (12.5\%). All cases involved vegetable farmers, sometimes interacting with farmers working in other production systems (e.g., livestock, arable crops). Marketing firms were involved in the innovations surrounding the long value chain (40\%). The R\&D actors (researchers, extension services) played an important role in $70 \%$ of the coupled innovations studied. Finally, other stakeholders were also involved, though to a lesser extent: public organizations (15\%) such as administrations or water agencies, NGOs and associations (12.5\%) such as trade unions and professional organizations, and input suppliers (10\%) such as plant breeders and input retailers. The organic vegetable sector was overrepresented with $47.5 \%$ of the cases compared to its share of the national agricultural area: 7,8\% of the area for fresh vegetables in 2019 (Agence Bio, 2020). A combination of organic and non-organic actors was involved in $15 \%$ of the cases.

The coupled innovations combined ACP practices at the field level with innovations at the STAFS level supporting their implementation. The latter were most frequently organizational (77.5\%), compared to institutional (32.5\%) and technical (22.5\%). In some case studies, they combined several types, mainly organizational and institutional (15\%) (Table 3). The agroecological farming practices fostered by the coupled innovations mainly revolved around breaking the cycle of targeted bioagressors (47.5\%, mainly through crop diversification) and organic integrated pest, weed and disease management (32.5\%, e.g., by stimulating or introducing natural enemies) (Table 3). The other practices related to the introduction of service crops (5\%), bioagressor monitoring (5\%), prophylactic measures $(2.5 \%)$, and a combination of several types of practices (7.5\%).

\subsection{Data analysis}

The data analysis was performed in four stages.

Step 1: we characterized the sociotechnical levers in each case study based on the collected data and the analytical framework (see 2.1). We grouped them by common functions.

Step 2: For each case study, we assigned the categories of the supplementary variables describing the conditions for the implementation of the coupled innovations and their evaluation (Table 2, section 2.1).

Step 3: We built a typology of the 40 coupled innovations by multiple correspondence analysis (MCA), followed by a hierarchical cluster analysis on the principal components (HCPC). The explanatory 
variables were the sociotechnical levers' function, translated as binary variables: "yes" for "function performed", and "no" for "function not performed". Thus, the HCPC grouped the innovation cases into the same cluster when they performed the same specific combination of lever functions. To identify the variables' categories that characterized each cluster compared to the others, a hypergeometric test was performed on the number of individuals (i.e. number of case studies) in Cluster X, which compared Category A of Variable $\alpha$ to the other clusters, for each cluster, each category and each variable. A p-value $<0.05$ revealed that for Variable $\alpha$, Category A was more present in Cluster X than in other clusters (Lê et al., 2008). We tested all explanatory and supplementary variables (See Step 2). All statistical analyses were conducted using R (v4.0.2), with the packages FactoMineR and ade4. To identify the variables' categories characterizing elements that played an important role in the functioning of each cluster's innovations, although not significantly specific to this cluster, we looked at the percentage of occurrence of each Category A for each Variable $\alpha$ and each Cluster X. These analyses supported a comprehensive cross-case study analysis to reveal generic types of coupled innovation, i.e., clusters, based on similar combinations of lever functions and provide an overview of the diversity of conditions for the innovation implementation and their evaluation.

Step 4: For the five coupled innovations studied in-depth, a detailed description was written as a "story" based on the analytical grid (Table 2). The aim is to capture the complex relations between sociotechnical levers, the functions they perform, the network involved, the ACP practices implemented and the conditions for innovation implementation. These complex relations cannot be captured using only categorical variables.

\section{Results}

In this section, we first present the identified sociotechnical levers grouped by functions (3.1), then the five clusters of coupled innovations (3.2.). In section 3.1., the numbers in brackets indicate the proportion of case studies in the overall sample for a given category, whereas in Section 3.2 they indicate the proportion of case studies in a given cluster for a given category. In the whole Results section, "N.S." stands for "not significant" and indicates p-value $>0.05$, “*” indicates $p$-value $<0.05$, “**” p-value $<0.01$ and “***” p-value $<0.001$.

\subsection{Levers performing key functions to overcome barriers to change in farming} practices

Through an inductive data analysis from our full sample $(n=40)$, we identified 17 sociotechnical lever functions (in italic), which we grouped into five lever meta-functions (in bold - Table 4). Several sociotechnical levers performed a variety of functions in each of the 40 cases. In this section, we 
present the lever functions by showing the link with the farming practice determinants it modifies (Table 1) and by giving examples of the corresponding sociotechnical levers from the case studies.

The first lever meta-function, "Providing material resources" (75\%, Table 4), comprises seven lever functions related to the direct or indirect provision of material resources at farm and STAFS levels (Table 1). The function Financial support (57.5\% of the Cs) is performed by providing free services (e.g., a decision-making support system in Cs13), access to resources at a lower price (e.g., the bulk purchase of inputs in Cs30), easier access to capital (e.g., pooling the investment capacity of several farmers in Cs27 and Cs31), or paid services (e.g., Cs1 to Cs9) (Table 4). Outlet guarantee (32.5\%) is fulfilled when there is a guarantee that the product yielded with the new practices (e.g., diversified production in Cs32) will be sold at an attractive price, e.g., thanks to specification requirements and a label for the consumers $(\mathrm{Cs37}, 40)$. Land pooling $(30 \%)$ is achieved by renting, exchanging or sharing land (e.g., Cs1 to Cs9). Some of the coupled innovations also provide Access to new inputs (17.5\%) (e.g., Cs30: varieties) and New equipment or access to facilities (10\%) (e.g., shelter infrastructure in Cs25). Some coupled innovations facilitate access to workforce (Workforce access, 12.5\%), for instance by pooling workforce (Cs27) or providing services (Cs6 and Cs8). Finally, some innovations afford workforce time savings (Time saving, 15\%), for example with each farmer specializing in specific tasks within pooled farms (Cs25 and Cs26).

The second meta-function, "Risk reduction", relates to a single function: Risk reduction (42.5\%) at farm level. It is performed, for instance by securing outlets (Cs32) or renting out land for high-value cash crop production instead of producing risky crops (carrots vs maize in Cs8). This function helps overcome the barriers that arise from farmers' risk aversion (Table 1).

The third meta-function, "Providing cognitive resources to farmers and other STAFS stakeholders" (77.5\%, Table 4), encompassed three lever functions targeting the filling of a gap in knowledge, data or know-how, i.e., improving cognitive resources (farm and STAFS level - Table 1). Knowledge provision was the second most performed function in our sample (62.5\%, Table 4). Coupled innovations performed it when knowledge, data or know-how is provided to certain actors (mainly farmers) by other actors (mainly public or private R\&D organizations), e.g., by the co-development of a decision support tool $(\mathrm{Cs} 11,13)$. We distinguished this function from Peer-exchange (35\%) among farmers, which is known to provide farmers with multiple cognitive and social resources (Mawois et al., 2019) that they appropriate more easily (e.g., exchanges through a social media Cs17 and 18). Knowledge production (32.5\%) stands either for the production of new knowledge through experiments (e.g., Cs29, Cs35), or for the formalization of stakeholders' empirical knowledge (e.g., Cs14,15). 
The fourth meta-function, "Creating or changing shared rules" (55\%, Table 4), relates to supporting change in the shared rules among stakeholders influencing farming practices (STAFS level-Table 1). Change or set of regulative rules (37.5\%, Table 4 ) is performed either through a legal entity (e.g., a cooperative for sharing equipment, land and workforce in Cs26, Cs27 and Cs28) or through contracts or charters (e.g., farming practice specification requirements to obtain a quality certification in Cs12 and Cs37). Change in normative rules (27.5\%) specifically relates to changes in role expectations (e.g., buyers from marketing firms expected to support crop diversification, in Cs22) or in norms (e.g., leased fields were to be returned in the same condition as at the beginning of the lease, in Cs5 and Cs6). Change in cognitive rules rarely played a role (7.5\%). This is performed when a stakeholder is changing others' paradigms or values, for example with an R\&D actor sensitizing buyers to take crop diversification into account when setting requirements to farmers, and not only marketing constraints (Cs22).

Finally, the fifth meta-function, "Facilitating stakeholders' interactions" (75\%, Table 4) consists of three lever functions that facilitate the multi-stakeholder interactions, and ultimately to foster change towards ACP (Table 1). It includes creating or strengthening knowledge infrastructure (Table 1). We found that Intermediation by intermediary actors was performed in most cases (67.5\%, Table 4). The intermediaries were mostly public extension services (in 15 cases), but also NGOs (3 cases), farmer organizations ( 3 cases) and other stakeholders (5 cases - researchers, technical committees, independent advisors). They handled various tasks: connecting stakeholders; facilitating the building of a common vision; organizing and facilitating meetings either to plan actions (e.g., a new production campaign in Cs20 and Cs21) or to exchange and formalize knowledge (e.g., between farmers in Cs14 and Cs15); mediating negotiations (between farmers and marketing firms in Cs22 and Cs37) or organizing the collection, production, formalization and translation of knowledge and its dissemination to various stakeholders (e.g., experimental stations in Cs32 and Cs33). Structuring of a new network (45\%) facilitates knowledge exchange or the organization of collective action, through a novel network infrastructure, e.g., farmer group buying together seeds from alternative varieties (Cs30). Finally, 20\% of the studied coupled innovations specifically fulfilled the function Facilitation of communication between stakeholders, with stakeholders that normally have little interaction with one another surrounding farming practices. For instance, in Cs28, a marketing firm, farmers and an agronomist discussed together pest dynamics, so as to plan rotations on the 35 involved farms to prevent the rapid spread of pests while respecting the marketing firm's requirements. We distinguished Structuring of a new network and Facilitation of communication between stakeholders from Intermediation, as the first two functions were crucial to overcome barriers for numerous innovations studied. Besides, they were 
383 not always performed by an intermediary, but sometimes by one of the core stakeholders, e.g., in 384 Cs19, the communication was facilitated by the organic cooperative. 
Table 4 - Sociotechnical lever functions performed in the coupled innovations studied. The numbers in the table designate the proportion in the overall sample or in a given cluster of the case studies which perform a given lever function or lever meta-function (line 'Meta-function'). When the presence of a lever function (occurrence $>50 \%$ ) or its absence (occurrence $<50 \%$ ) characterizes significantly the cluster according to the hypergeometric test, an indication of the significance is given: $*$ for $p$-value<0.05, $* *$ for $p$-value $<0.01$ and $* * *$ for $p$-value<0.001.

\begin{tabular}{|c|c|c|c|c|c|c|c|}
\hline \multirow{2}{*}{$\begin{array}{l}\text { Sociotechnical lever } \\
\text { meta-functions }\end{array}$} & \multirow[b]{2}{*}{ Sociotechnical lever functions } & \multicolumn{6}{|c|}{ Occurrence of the functions (\%) and statistical significance for cluster determination } \\
\hline & & $\begin{array}{l}\text { In the overall } \\
\text { sample }(n=40)\end{array}$ & $\begin{array}{l}\text { In Cluster } 1 \\
\quad(n=9)\end{array}$ & $\begin{array}{l}\text { In Cluster } 2 \\
(n=10)\end{array}$ & $\begin{array}{l}\text { In Cluster } 3 \\
(n=8)\end{array}$ & $\begin{array}{l}\text { In Cluster } 4 \\
(n=4)\end{array}$ & $\begin{array}{l}\text { In Cluster } 5 \\
(n=9)\end{array}$ \\
\hline \multirow{8}{*}{$\begin{array}{l}\text { Providing material } \\
\text { resources }\end{array}$} & Access to new inputs & 17.5 & $56 * *$ & 0 & 12.5 & 25 & 0 \\
\hline & Land pooling & 30 & 0* & 0* & 0* & 75 & $100 * * *$ \\
\hline & New equipment or access to facilities & 10 & 0 & 0 & 0 & $100 * * *$ & 0 \\
\hline & Workforce access & 12.5 & 0 & 0 & 0 & $75^{* *}$ & 22 \\
\hline & Time saving & 15 & 11 & 30 & 0 & 50 & 0 \\
\hline & Financial support & 57.5 & $88^{*}$ & $10 * * *$ & 37.5 & 50 & $100 * *$ \\
\hline & Outlet guarantee & 32.5 & 11 & 20 & $100 * * *$ & 50 & 0* \\
\hline & Meta-function & 75 & 100 & 40 & 50 & 100 & 100 \\
\hline Risk reduction & Risk reduction (42.5\%) & 42.5 & $0 * *$ & 30 & 63 & 0 & $100 * * *$ \\
\hline \multirow{4}{*}{$\begin{array}{l}\text { Providing cognitive } \\
\text { resources to farmers and } \\
\text { other STAFS } \\
\text { stakeholders }\end{array}$} & Knowledge provision (62.5\%); & 62.5 & 89 & 80 & $100 *$ & 25 & $0 * * *$ \\
\hline & Knowledge production & 32.5 & $89 * * *$ & 40 & 12.5 & 0 & 0* \\
\hline & Peer exchange (35\%) & 35 & 11 & $100 * * *$ & 0* & 75 & $0 *$ \\
\hline & Meta-function & 77.5 & 100 & 100 & 100 & 100 & 0 \\
\hline \multirow{4}{*}{$\begin{array}{l}\text { Creating or changing } \\
\text { shared rules }\end{array}$} & Change or set of new regulative rules & 37.5 & $0 * *$ & $10^{*}$ & $87.5^{* *}$ & 75 & 44 \\
\hline & Change in normative rules & 27.5 & $0 *$ & $0 *$ & 12.5 & 75 & $78 * * *$ \\
\hline & Change in cognitive rules & 7.5 & 0 & 0 & 25 & 0 & 11 \\
\hline & Meta-function & 55 & 0 & 10 & 100 & 100 & 100 \\
\hline \multirow{4}{*}{$\begin{array}{l}\text { Facilitating stakeholders' } \\
\text { interactions }\end{array}$} & Structuring of a new network & 45 & $89 * *$ & 50 & 63 & 0 & $0 * *$ \\
\hline & $\begin{array}{l}\text { Facilitation of communication } \\
\text { between stakeholders }\end{array}$ & 20 & 22 & 10 & $50 *$ & 25 & 0 \\
\hline & Intermediation & 67.5 & 78 & $100 * *$ & 88 & 50 & $11 * * *$ \\
\hline & Meta-function & 75 & 100 & 100 & 100 & 50 & 11 \\
\hline
\end{tabular}




\subsection{Five clusters of coupled innovations each performing specific lever functions} in a variety of ways and conditions

Using the 17 sociotechnical lever functions as explanatory variables, we conducted the MCA analysis followed by the HCPC classification on the first three components found by the MCA. It revealed five clusters of coupled innovations, each characterized by a specific combination of lever functions (maximization of the inertia gain, Fig. 1). The three-component model provided a good fit, explaining $55 \%$ of the variance. All the correlated variables $(p<0.01)$, i.e. the lever functions explaining each component, were identified and sorted according to their correlation with the components (Figure 1). Figure 1.a and 1.b summarize the latter information as well as the relation of the clusters to the three main components and the lever functions. For both figures, the further a cluster is positioned at one side of a component axis, the stronger is the presence within this cluster of the lever functions indicated on that side, and the weaker is the presence of the functions indicated on the opposite side. For instance, in Fig 1.a, the cluster 5 grouped innovations where the functions Change in normative rules, Risk reduction, Land pooling and Workforce access are very present, and the functions Knowledge provision, Knowledge production, Structuration of a new network and Intermediation are very little present or absent.

In the following sections, for each of the five clusters, we first present the combination of lever functions that characterize the cluster, the diversity of coordinated actions performing them and their links with ACP practices. Then we present the diversity of conditions for their implementation and their impacts on pesticide use and bioagressor management. We differentiate the categories of explanatory or supplementary variables that are significantly specific to a cluster, from the ones that are not statistically specific but which are largely present in the cluster and meaningful for describing it. We show the difference by using N.S abbreviation for "Not Significant". Finally, for each cluster, we show how sociotechnical levers' actions, functions and ACP practices articulate, with presenting an "in-depth case studied". The Table 3 above indicates the case studies' cluster, identification number and nature. Figure 2 presents the cluster ideotypes, which synthesize for each cluster how the typical coordinated actions performed functions supporting the implementation of ACP. 
a)

Peer exchange ***

Time saving ***

New equipment or access to facilities **

Knowledge provision*** Knowledge production *** Structuring of a new network*** Intermediation***

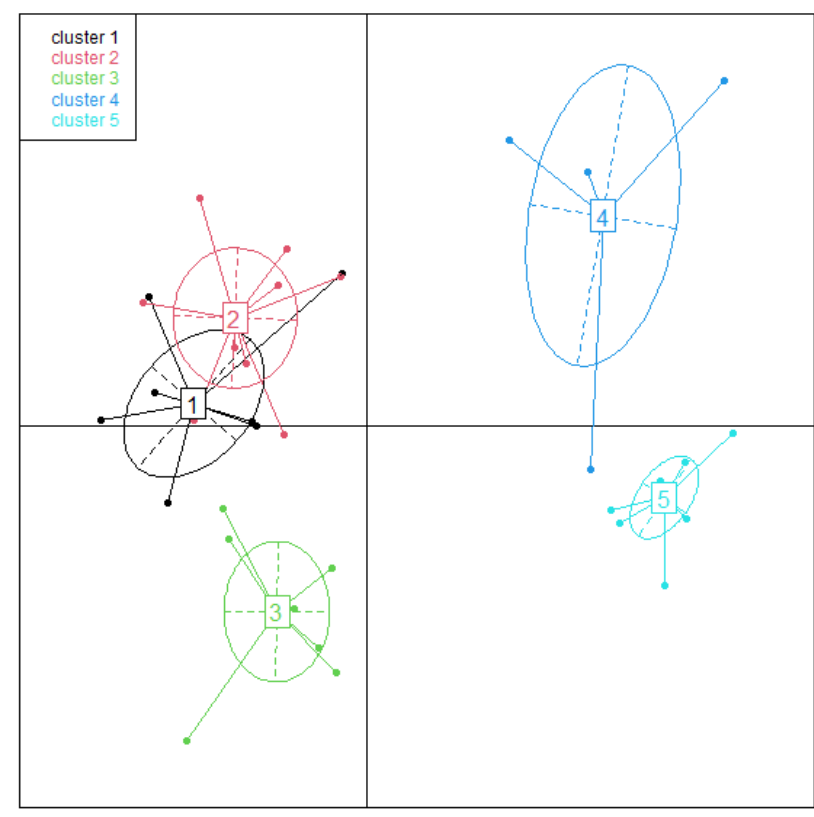

\section{Component $1(27 \%)$}

Change in normative rules*** Risk reduction **

Land pooling*** Workforce access***

Change in cognitive rules **

Facilitation of communication between stakeholders ** Outlet guarantee **

Risk reduction ***

b)

\section{Component 3 (13\%)}

Change or set of new regulative rules***

Facilitation of communication between stakeholders **

Outlet guarantee***

New equipment or facilities access****

Change in cognitive rules ** Facilitation of communication between stakeholders ** Outlet guarantee ** Risk reduction ***

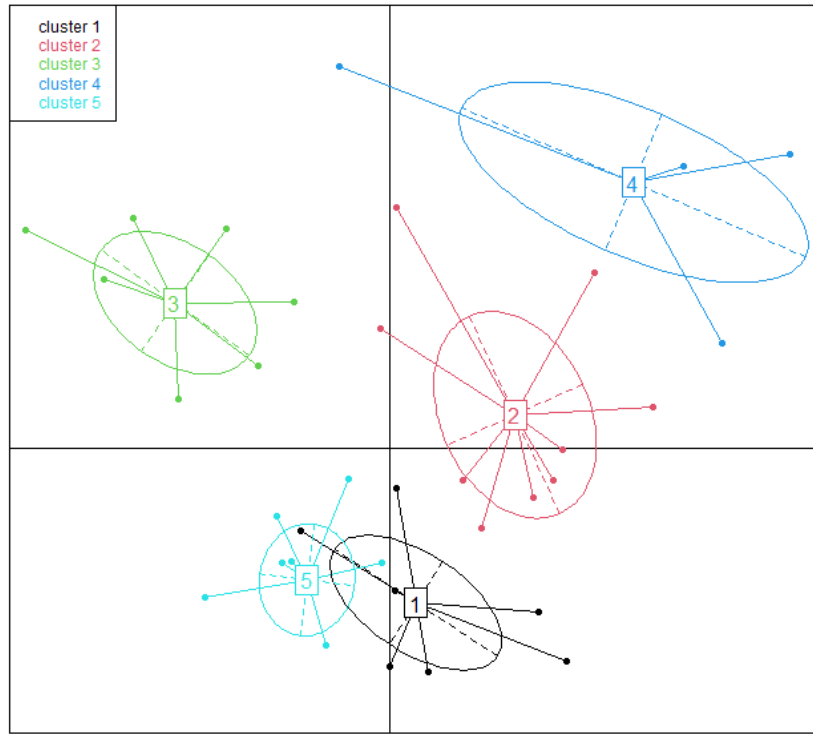

Financial support ***

Figure 1 - Distribution and grouping of the 40 coupled innovations according to the sociotechnical lever functions performed. a) Distribution of the innovation cases grouped by clusters according to Components 1 ( $27.2 \%$ of the variance) and $2(14.2 \%)$ of the MCA and their correlated variables. b) Distribution of the cases according to Components 2 (14.2\%) and $3(13.3 \%)$ and their correlated variables. The significance of the correlation between the lever functions and the components is indicated with $* *$ for $\mathrm{p}$-value $<0.01$ and $* * *$ for $\mathrm{p}$-value $<0.001$. The distribution according to Components 1 and 3 shows little difference with Fig.1.a), hence it is not presented. Ellipses are centered on the centroids of the groups. 
3.2.1. Cluster 1: Co-development of knowledge infrastructure partly coupled with input production and provision to foster the implementation of agroecological practices Cluster 1 is comprised of nine coupled innovations and is characterized by the combination of the following lever functions: Knowledge production (89\%***), Structuring of a new network $(89 \% * *)$, Financial support (78\%*) and Access to new inputs (56\%*); and also performing, for the largest share, Knowledge provision (89\% N.S.) and Intermediation (78\% N.S) (Table 4 ; Fig. 2a). For half of the cases studied, the knowledge produced and provided was explicitly associated with the use of new specific input (e.g., a biocontrol agent in Cs29, Cs35 and Cs36) or new varieties (Cs30, Cs31). For the other half, this knowledge related to a range of agroecological practices, tested on experimental stations (Cs32 and Cs33) or in an agroforestry network (Cs34), or advised through a Decision-Making Support System (Cs13). Dynamic and structured new networks produced and provided this knowledge. Intermediation was achieved by a professional organization (Cs13, Cs33), public R\&D (Cs29, Cs32, Cs35 and Cs36) or a cooperative (Cs31). It facilitated interaction within networks producing and sharing knowledge, comprised of farmers, public organizations and private companies. They were financially supported mostly by public R\&D subsidies ( $\operatorname{Cs} 29, C s 32, C s 33, C s 35$ and $C s 36$ ) as well as marketing or input supply firms (Cs13, Cs32 and Cs33).

The coupled innovations in Cluster 1 specifically relied on technical innovations (56\%*) to implement levers, such as new production techniques for biocontrol input production (Cs29, Cs35, 36) (Fig. 2a). Yet organizational innovations were predominant (89\%), as all the innovations involved novel networks of actors. The stakeholders shared professional ties (89\%*). The conditions of success, according to the interviewees, depended on the degree of reliance on the availability of material and human resources. Resources were the primary barrier $(89 \% * * *)$, and the main resources were capital $(30 \% * *)$ and inputs $(30 \% * *)$. Moreover, in $89 \%$ of the cases studied, the key factors for lasting innovation revolved around human resources (presence of a stakeholder dedicated to coordination, frequent solicitations, or stakeholder flexibility). We also noted that the innovations were mainly initiated by public R\&D actors $(67 \%$ N.S.), and primarily within the organic sector $(67 \%$ N.S.). Finally, the stakeholders interviewed considered that these coupled innovations showed rather good results for pesticide reduction ( $56 \%$ N.S.) and bioagressor reduction (67\% N.S.).

Case 29, which we analyzed in-depth, shows how the above-mentioned elements can be concretely combined to foster the implementation of new farming practices in a given territory. This coupled innovation consisted in developing a local supply of banker plants and natural enemies, and the related technical support. The local organic farmers' association brought together 15 farmers around this project (Intermediation and Structuring of a new network). In 2014, they initiated a R\&D group funded by French public subsidies (Financial support). The project was carried out in partnership with the INRA 
experimental station Alenya and the local farming high school. These two partners were in charge of 460 developing and testing growing techniques for banker plants and natural enemies, and for supplying 461 the organic farmers' association with the relevant inputs (Knowledge production, Access to new 462 inputs). The project also involved a plantlet nursery. The association's technical advisor coordinated 463 the project: he connected the participants, defined the shared goal, formalized knowledge (Knowledge 464 production), translated and transferred it to the high school and the farmers (Knowledge provision), 465 and delivered the banker plants to the farmers (Access to new inputs), with the support of a technician 466 and researchers from INRA (intermediation and Structuring of a new network). The R\&D group allowed 467 for building lasting cooperation between the association and the high school, which continued even 468 after the subsidies ended (2017). This coordination afforded total control of black aphids on 469 Cucurbitaceae crops on participating farms. The main barriers encountered were (i) economic viability, 470 (ii) the difficult sourcing of inputs to breed natural enemies (e.g., samples of pure strains of black 471 aphids) and (iii) the lack of farmers' involvement in the production process. The key factors of success 472 were shared motivation, funding, access to the required equipment, inputs and facilities, a dedicated 473 facilitator, and relevant know-how. 
a) Cluster 1: Co-development of knowledge infrastructure partly coupled with input production and provision to foster the

implementation of agroecological practices

cluster 3: (Re)structuring of the food value chain to support the implementation of agroecological farming practices

* Action carried out by only one of the actors b) Cluster 2: Facilitation of peer exchange among farmers around agroecological farming practices
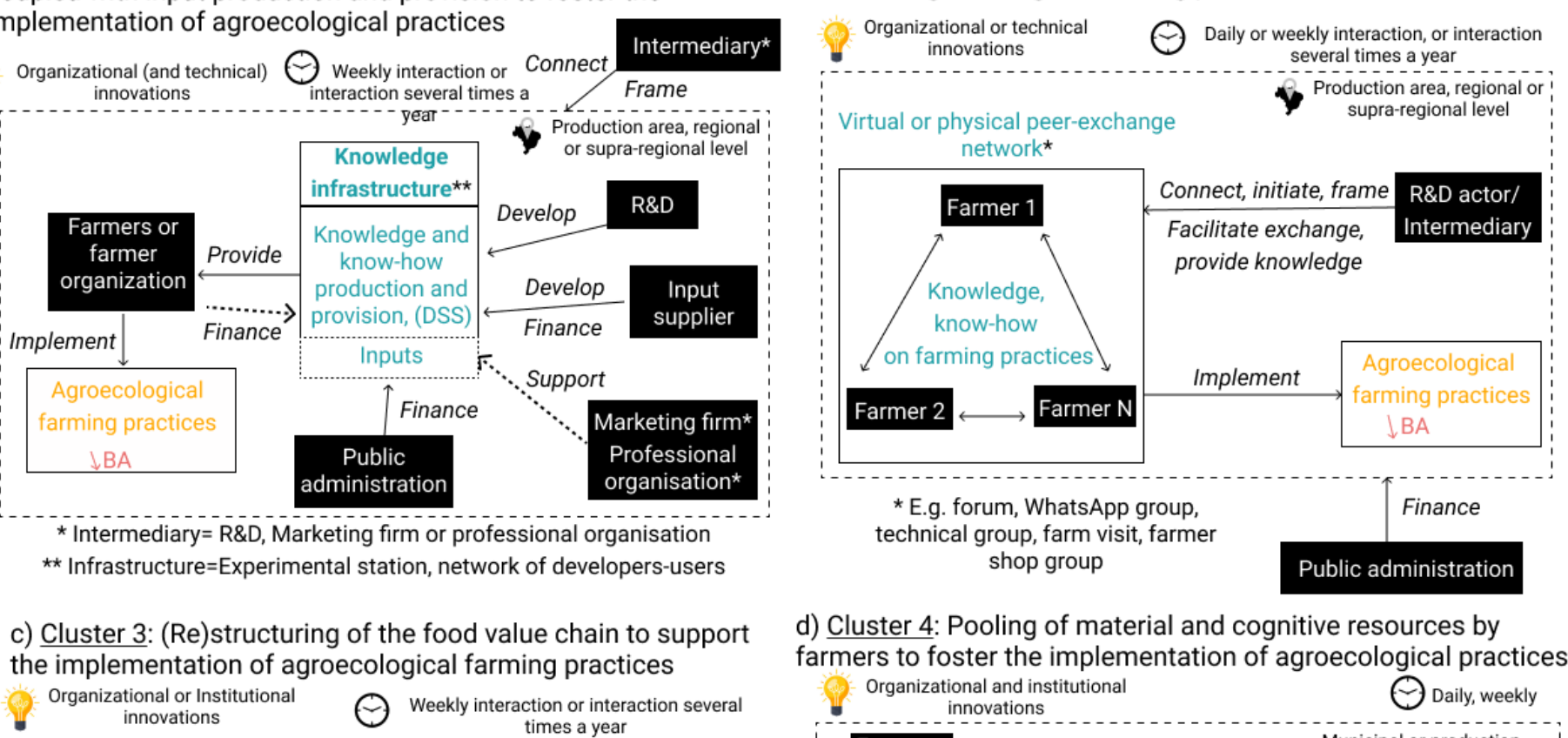

d) Cluster 4: Pooling of material and cognitive resources by farmers to foster the implementation of agroecological practices Q. Organizational and institutional

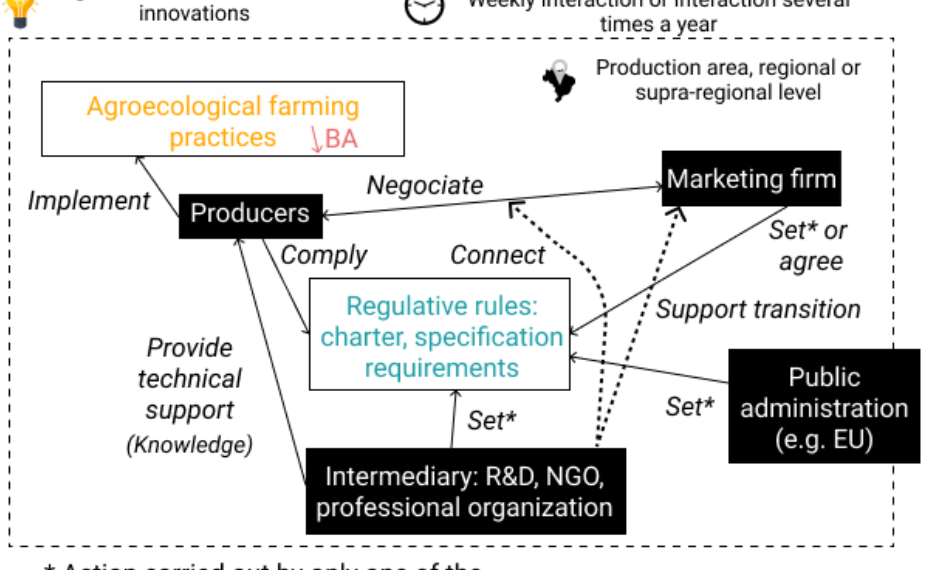

innovations

$\Theta$ Daily, weekly

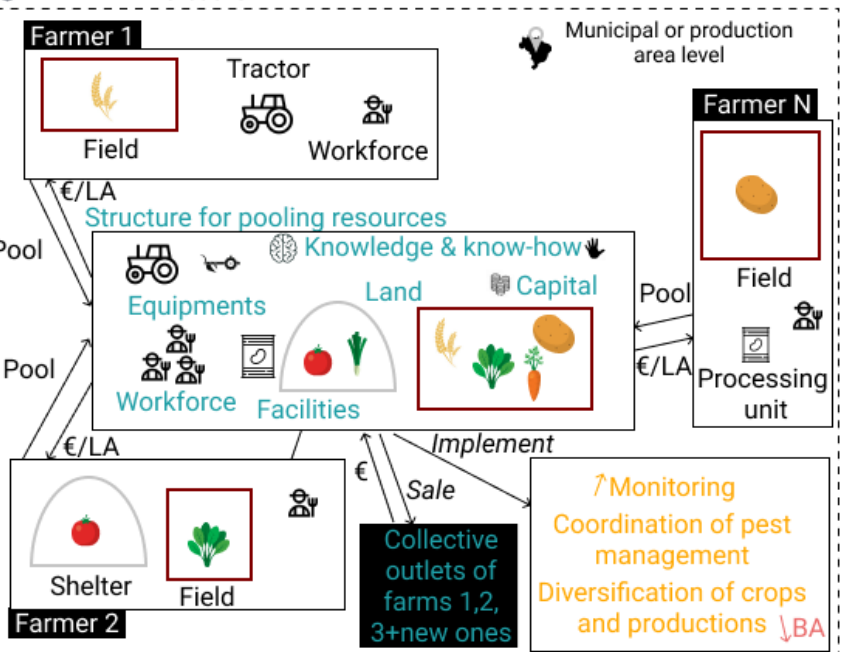

e) Cluster 5: Renting or exchanging fields to diversify crop rotation

Q Organizational innovations $\theta$ Yearly

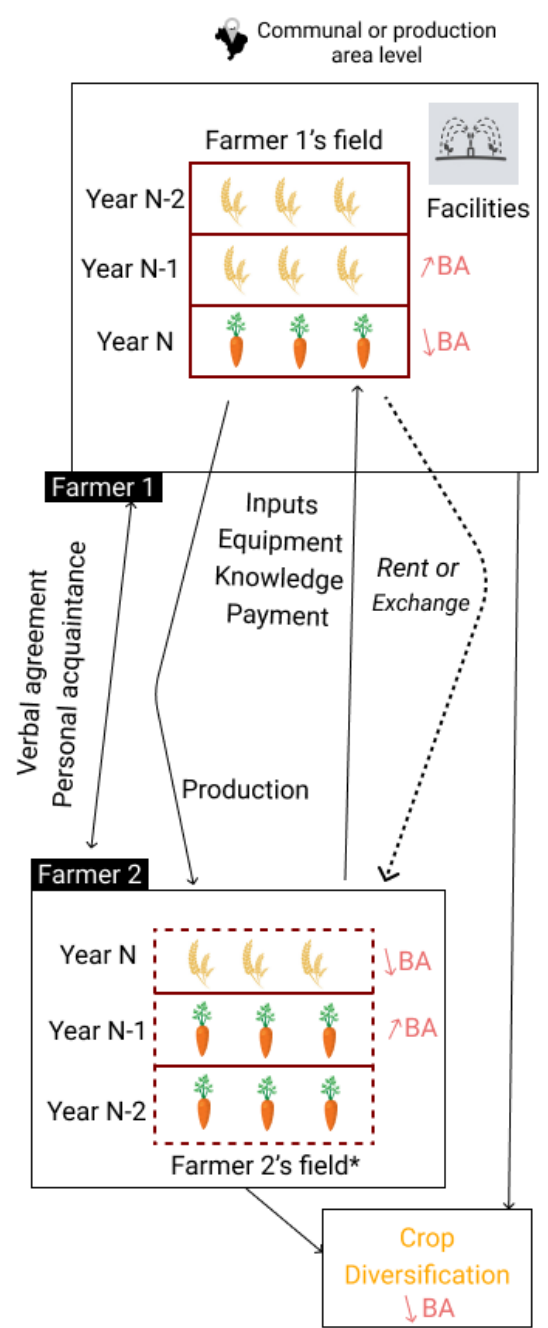

*Can also be nomadic (without its own fields)

Figure 2 - Ideotypes of coupled innovation clusters. Farming practices are indicated in orange, the objects of coordination in blue, and the bioagressors (BA) managed in red. The black squares represent the stakeholders. The large dotted frames represent the territory across which the coordination is taking place (some actors can be outside, e.g., Clusters 1 and 2 , or both inside and outside, e.g., Cluster 3). The dotted arrows represent optional actions by stakeholders. a) DSS = Decision-Making Support System. While input provision is optional, it was a key and original feature of half the coupled innovations studied. c) EU = European Union. d) $€ / L A=$ benefits redistributed as a share of the resources pooled (especially land area). Organic farming is overrepresented within Clusters 1 to 4. 
3.2.2. Cluster 2: Facilitation of peer exchange among farmers around agroecological farming practices

Cluster 2 is comprised of 10 coupled innovations, all performing Peer exchange (***) and Intermediation (***) (Table 4; Fig. 2b). We can also note that in this cluster, Knowledge provision was performed in $80 \%$ of the cases, Knowledge production in $40 \%$ of the cases, and Structuring of a new network in $50 \%$ of the cases (N.S.). This cluster encompasses coupled innovations that mainly revolved around the facilitation of a new or existing peer-exchange network of vegetable farmers and the transfer of formalized knowledge to these farmers. Most of the networks were facilitated by public extension services, focusing on knowledge about a specific agroecological technique (e.g., leek as green manure in Cs14; also Cs10, Cs15 and Cs23), the practices of the farms visited (Cs16), or simply the practices of the farmers around the table (Cs10, Cs20 and Cs21). In some cases, tools were used to support this facilitation: WhatsApp groups (Cs17 and Cs18), and a web forum linked to an application that supported pest identification, mapping and provided knowledge on their management (Cs11). As in Cluster 1, these networks constitute a knowledge infrastructure.

The innovations in Cluster 2 were initiated by public R\&D actors $\left(70 \%^{*}\right)$, with a view to improving farming practices (agronomic motivations, 60\%*) (Fig. 2b). Knowledge acquisition was a major factor driving the development of the innovations $(40 \% *)$. Knowledge was also the main resource needed $(50 \% * *)$. The innovations mainly involved cooperation between farmers and R\&D actors $(100 \%$ of the cases), public administrations ( $20 \%$ of the Cs) or marketing firms ( $30 \%$ of the Cs), at the production area level $(70 \%$ of the Cs) or higher ( $30 \%$ of the Cs), through regular meetings (several times a year, weekly or daily for $90 \%$ of the cases). In half of the cases, the innovation arose from purely professional relations, and in the other half from personal acquaintances. The key factors of lasting cooperation were "frequent solicitations" ( $40 \%$ N.S.) and the "presence of a stakeholder dedicated to coordination" (40\% N.S.). The main barriers were "distance" (40\% N.S.) and "relational" challenges ( $30 \%$ N.S.). Half of the cases mostly involved actors from the organic sector. The impact on bioagressors and pesticide reduction was only evaluated in $30 \%$ of the cases, and was positive.

Case 23, which we analyzed in-depth, illustrates the characteristics of Cluster 2, with the co-design of diversified crop rotations (species, varieties and service crops). It was initiated and led by INRA Alenya researchers as part of the European project Diverlmpacts (2017-2022) (Financial support) to develop methods to facilitate crop diversification, and thus reduce bioagressor pressure. It involved the extension services of the local chamber of agriculture, four organic farmers, and two organic marketing firms selling the vegetables. The researchers and extension service agent identified and brought the other stakeholders onboard (Structuring of a new network and intermediation), as well as identifying organizational, technical and marketing barriers to crop diversification for vegetable farmers on the 
Roussillon region (Knowledge production). They then co-designed diversified cropping systems with the farmers and marketing firms (Intermediation, Peer-exchange and Knowledge diffusion). The INRA researchers created tools for the stages of 'diagnosis' and 'co-design', with the support of the participants of the European project (Knowledge production). The INRA researchers and technicians designed and led experiments on crop diversification on their experimental station, from cropping to sales, to serve as a basis for knowledge production (Knowledge production) and exchange (Peerexchange, Knowledge diffusion and Intermediation). The researchers and extension services structured the evolution of the project, ensuring that the other stakeholders' expectations were met (Intermediation). They then capitalized on the co-produced knowledge. According to the interviewees, the main barriers were the high cost of the overall methodology, and difficulties in mobilizing a diverse range of farmers (especially conventional farmers). The main conditions of success were shared motivations, the availability of knowledge, the financing of researchers and advisors, involving a diverse range of stakeholders (especially marketing firms), and tailored work with the farmers and marketing firms. According to the extension services involved, the cropping system prototypes that were designed would have never been imagined by the farmers alone. One was already implemented in 2019.

\subsubsection{Cluster 3: (Re)structuring of the food value chain to support the implementation of} agroecological farming practices

Cluster 3 is comprised of eight coupled innovations that relied specifically on Outlet guarantee $\left(100 \%^{* * *}\right)$, Change or set of new regulative rules $(87,5 \% * *)$, Knowledge provision $(100 \% *)$, and the Facilitation of communication between stakeholders (100\%*) (Table 4; Fig. 2c). The innovations fostered change in practices by guaranteeing an outlet for crops grown using alternatives to pesticides: biological control and integrated pest management (Cs12, Cs37), organic production (Cs24, Cs39, Cs40), diversification of production (Cs19, Cs22), or following strict prophylactic measures (Cs38). They also provided farmers with the new knowledge needed to implement these alternative practices. Changes in farming practices were structured and enforced through regulatory rules (except in Cs19), for instance specific requirements enforced through a certification process (Cs37). Intermediation (87.5\% N.S) and the Structuring of a new network (62.5\% N.S.) are also important lever functions in this cluster. These two functions consist in facilitating new or existing networks and supporting communication between their members around agroecological practices, the barriers to their implementation, and the levers to overcome them.

The coupled innovations in Cluster 3 specifically revolved around institutional innovations $(100 \% * * *$, e.g. a new certification for alternative farming practices in Cs12, Cs37, Cs38), complemented by organizational innovations (50\%), They were implemented at production area level $(62.5 \%$ N.S.) or 
higher (37.5\% N.S.) (Fig. 2c). The innovations were characterized by multi-year contracts $\left(75 \%{ }^{*}\right)$. They involved mainly coordination between farmers, marketing firms and R\&D, and for half the cluster, NGO support $\left(50 \%^{* * *}\right)$. The relations between the stakeholders were exclusively professional $(100 \% * *)$. They met either weekly or several times a year (87.5\% cumulated). These innovations were initiated overwhelmingly by marketing firms $\left(62.5 \%^{* *}\right)$, and the motivations were initially economic $(62.5 \% *)$. The main barriers were competition and limited availability of the resources needed $(87.5 \%$ cumulated), namely "outlets" (37.5\%*) as well as "resource actors" (50\% N.S.). The key conditions of coordination success were economic results and the actors' flexibility ( $75 \%$ cumulated). Most of the innovations could not be evaluated by the interviewees, either because they had only recently been implemented, or because the person interviewed had not received sufficient feedback from farmers. We also noted that the involved actors were largely from the organic sector (62.5\% N.S.).

Case study 37 exemplifies the articulation of the above-mentioned elements (Fig. 2c) in the case of the structuring of an alternative value chain around soil conservation management practices. This project was initiated in 2017 by a French NGO, originally co-founded, among others, by alternative agronomists who are known figures of conservation agriculture and agroforestry, a cook, and the head manager of a marketing firm. It was financed and managed mainly by marketing firms, but also by representatives of other stakeholders such as farmers and agronomists. These actors promoted agroecological systems guided by the principles of conservation agriculture (Palm et al., 2014) at national level, to foster soil life and reduce soil-borne pest and disease pressure. The NGO advocated a change in the farming paradigm (Change in cognitive rules) and the construction and dissemination of knowledge on conservation agriculture systems (Knowledge production and diffusion), for instance by organizing a seminar bringing together farmers and all public and private R\&D actors (Intermediation). The NGO's employees (mainly agronomists) connected marketing firms and farmers (Structuring of a new network), and supported a change in the practices of both types of stakeholders towards conservation agriculture. They formalized specification rules for vegetable production that commit farmers to gradually shifting their practices towards conservation agriculture (Change or set of new regulatory rules). They formalized a charter, and sensitized and monitored marketing firms to ensure that the farmers involved were paid at a fair price and that the marketing firms changed their practices (e.g. changing sorting practices to accept potatoes with irregular shapes) (Change or set of new regulatory rules, Outlet guarantee). They provided technical support to assist the farmers' transition either directly or by connecting them with $R \& D$ experts in conservation agriculture in their region (Knowledge diffusion, Intermediation). Finally, they informed consumers, for instance with a new label for melons in the south-east of France. The main conditions of success were significant 
private funding, facilitation by the NGO acting as an intermediary, the involvement of marketing firms providing outlets, and networks of farmers historically involved in alternative farming practices.

\subsubsection{Cluster 4: Pooling of material and cognitive resources by farmers to foster the implementation of agroecological practices}

Cluster 4 encompasses four coupled innovations, characterized by two functions: New equipment or access to facilities $(100 \% * * *)$, and Workforce access $\left(75 \%^{* *}\right)$ (Table 4 ; Figure $2 \mathrm{~d}$ ). The provision of other farm material resources is also important in this cluster: Land pooling (75\% N.S.), Time saving (50\% N.S.), Financial support (50\% N.S.) and Outlet guarantee (50\% N.S.). Peer-exchange (75\% N.S.), Change or set of new regulative rules (75\% N.S.) and Change of normative rule (75\% N.S.) play a significant role as well. The farmers pooled land, equipment, facilities, workforce, outlets, capital or knowledge, facilitating access to missing resources to implement agroecological practices, for instance shelter to produce specific crops (Cs25) or an agronomist to coordinate planting dates according to the wind direction so as to limit flows of melon whiteflies, thrips, aphids and powdery mildew (Cs28). The structuring of this coordination relied on the involvement of legal entities (in all cases except Cs25; e.g. a machinery cooperative to share tools) and the setting of norms, responsibilities, duties, and roles (in all cases except Cs27).

Cluster 4 covers four coupled innovations implemented mainly on a small scale at communal level $\left(75 \%^{*}\right)(C s 25, C s 26, C s 27)$, but also on a large scale at production area level (island of Guadeloupe in Cs28) (Fig. 2d). These were specifically initiated by farmers $\left(100 \%{ }^{*}\right)$, with some also involving R\&D actors (one case) or a marketing firm (one case). The coordination was carried out by stakeholders who tended to be connected through friendship ties $\left(50 \%{ }^{*}\right)$, but also personal acquaintance $(50 \%$ N.S.). It specifically took place in daily meetings $(75 \% *)$. These coupled innovations involved organizational $(100 \%)$ and institutional (75\%) innovations. The small-scale pooling initiatives were specific to organic farming (75\% N.S.). They were built on long-term formal contracts $(75 \%)$ or simple verbal agreements (Cs25). The key conditions of success appear to have been a shared desire to achieve this coordination, proximity between farmers, adaptability, and trust. The impact on bioagressor and pesticide use could only be evaluated in two cases, where the innovations were considered to have a positive impact on bioagressors (Cs25, Cs26).

Case 27 exemplifies the innovations in Cluster 4, at a small scale. Four farmers from a French agricultural equipment cooperative converted to organic together starting in 2014, and initiated a R\&D group in 2015. They were supported by the regional federation of equipment cooperatives and an external coach. Thanks to a specific legal status (SEP, "Société En Participation"), they structured the pooling of their land and crop rotations, inputs supply, workforce and sales proportionally to the surface provided (Change or set of new regulative rules, Providing material resources), while 
remaining independent farms. They also created an equipment cooperative for the storage and packaging of vegetables and tools (e.g., for weeding). The coach, who visited the farmers every two months, facilitated interaction between them and the work on existing or new projects (Intermediation). The coordination between the farmers facilitated and sustained access to a skilled workforce, improved effectiveness through the sharing of tasks, increased access to the equipment and facilities needed, and increased the value generated per hectare. It also promoted knowledge exchange between peers (Peer exchange). It then fostered crop diversification, known to reduce bioagressor pressure. It also fostered the conversion to organic farming of other farmers on the territory. The key conditions of success were shared dynamics and vision, trust and involvement in the group, financial support (initially from the R\&D group for the coach and then banks for the required investments), and economic success. The main difficulty was managing this complex system (administration, human resources).

\subsubsection{Cluster 5: Renting or exchanging fields to diversify crop rotation}

Cluster 5 is comprised of nine coupled innovations characterized by the following levers functions: Land pooling $\left(100 \%^{* * *}\right)$, Financial support $\left(100 \%^{* *}\right)$, Risk reduction $\left(100 \%^{* * *}\right)$ and Change in normative rules (78\%***) (Table 4; Fig. 2e). According to our interviews, the cases did significantly not involve Cognitive resources provision $\left(0 \%^{*}\right.$ to $\left.{ }^{* * *}\right)$ or the Structuring of a new network $\left(0 \%{ }^{* *}\right)$, and very little intermediation $(11 \% * *)$. The cases enabled crop diversification through field exchange or renting between vegetable farmers and other farmers (arable farmers in Cs1 to Cs9, as well as stockbreeding farmers in Cs4), between two vegetable farmers (Cs5) and between a landowner and a processing firm (potatoes, in Cs7). The farmers hosting high-value vegetable crops were always compensated for the rental or exchange, providing them with financial support without associated economic risk.

Cluster 5 covers nine coupled innovations, all fostering crop diversification to break bioagressor life cycles $\left(100 \%^{* * *}\right)$, especially of soil-borne pests and diseases $\left(44 \%^{*}\right)$ (Figure $\left.2 \mathrm{e}\right)$. These organizational innovations ( $100 \%$ N.S.) specifically applied at the communal level $(66 \% *)$, and mostly revolved around open-field exchange (only Cs5 was under shelter). They were characteristically initiated by farmers $\left(89 \%^{* * *}\right)$, for sanitary reasons $\left(89 \%^{* * *}\right)$. Conventional farmers $\left(100 \%^{* * *}\right)$ were also the main stakeholders of the coordination $\left(67 \%^{* *}\right)$, based on yearly interaction $\left(67 \%^{* *}\right)$ and informal agreements (78\% N.S.). In most cases (all but one), the stakeholders were personally acquainted, as friends, family or neighbors. The main barriers were land (44\%), and conflict between the lessor and the tenant around the management of land and/or infrastructure (relational issues, 33\%). Distance was also a barrier in two cases, as the transport of workers and equipment is costly. The key condition 
of success was trust, both to initiate the coordination $\left(66 \%^{* * *}\right)$ and to sustain it $\left(78 \%{ }^{* * *}\right)$. In several cases, the economic balance also initially played a distinctive role $(33 \% *)$. According to interviewees, these exchanges or rentals allowed for reducing bioagressor pressure $(89 \% *)$. However, in two cases, the interviewees reported an increase in herbicide use either to guarantee that the weed pressure would not increase and to strengthen trust (Cs9), or to deal with regrowth of cover crops' plants in a carrot crop from previous arable rotations (Cs2).

Case 5 exemplifies how the coupled innovations in Cluster 5 can be implemented. Two farmers, P1 and $\mathrm{P} 2$, owned two farms $12 \mathrm{~km}$ away from each other, and were friends. P2 was looking for sheltered space where no Brassicaceae had been cropped over the last few years to grow radishes with limited bioagressor pressure (whitefly, mildew, cabbage fly). P1 had free sheltered plots where he had stopped growing salads for economic reasons. He thus agreed to rent out the shelter (land pooling) to P2 for $€ 1,800 /$ ha (Financial support), through a verbal agreement. P2 had to return the shelter in its original condition (Change in normative rules). The main reported barriers were the distance, the farmers' desire to be independent on their own land, and the wear and tear of paths and facilities. The key factors of success were good communication about each partner's needs (e.g., specific soil treatment), exchange around crops requiring little intervention, the compatibility of the two farmers' cropping systems (e.g., P1 having free plots when P2 needed them) and of the facilities. As a result, P1 and P2 diversified their crop rotations, without the need for P1 to develop new knowledge to grow a new crop, invest in new equipment (in this case a radish seeder), or find new outlets.

\section{Discussion}

\subsection{Providing knowledge on existing coupled innovations to support innovation} design and niche management

Exploring alternatives to the dominant regime through the design of coupled innovation is a new research avenue (Brun et al., 2021; Meynard et al., 2017; Salembier et al., 2020). We believe that 'tracking down coupled innovations' can play a key role in this process, by supporting the design of the innovations required to achieve the sustainable transition of agrifood systems (Meynard et al., 2017). The studied coupled innovations did not necessarily result from a purposively coordinated design process as put forward by Meynard et al. (2017). Yet, they developed into inspiring innovations combining innovative farming practices and novelties at the agrifood system level supporting their implementation. In this section, we show how the knowledge we produced on the 40 coupled innovations studied can support different phases of the design process: concept exploration, detailed proposals and implementation (Hooge et al., 2016; Romera et al., 2020). 


\subsubsection{Existing coupled innovations as inspiration to explore coupled innovations} concepts in other contexts

Our study revealed five ideotypes of coupled innovation that performed combined sociotechnical lever functions in consistent ways to foster the implementation of ACP. Monographic studies have already analyzed in depth these types of innovation (e.g., for Cluster 1, Salembier et al., 2020 ; for Cluster 2, Cerf et al., 2017; Compagnone, 2019; for Cluster 3, Berthet and Hickey, 2018; Bui et al., 2016; Magrini and Duru, 2014; for Cluster 4, Lucas et al., 2018; for Cluster 5, Clément et al., 2019; Soulard, 2014). For instance, the Cluster 3's type of innovation (restructuring of the food value chain) is explored by studies of alternative value chains, which foster the implementation of crop diversification in arable and vegetable farming systems or agroecological animal husbandry (Berthet and Hickey, 2018; Bui et al., 2016; Magrini and Duru, 2014). Salembier et al. (2020) have contributed to formalizing knowledge on coupled innovations similar to the ones from Cluster 1. They analyzed a NGO-farmer network, which co-develop equipment for agroecological practices suited to farmers' specific needs in vegetable, arable, vineyard and orchard productions. It shows that our clusters are generic: they are not limited to vegetable farming systems and ACP, but applied to similar innovations which were developed in other sectors and/or to support the implementation of other types of practice. Yet our sample was limited $(n=40)$. As a perspective, it would be very valuable to confront our ideotypes to more case studies, in the same context (vegetable farming systems and ACP) and in others (other productions and/or practices). This would allow to better assess the genericity of our ideotypes and, if appropriate, to complement them with new ones.

The knowledge we produced could support agrifood system stakeholders confronted either (i) to a problem around a practice or (ii) to a problem around specific barriers they have identified. For instance, as regards the first point (i), many scholars have pointed out that crop diversification is locked out in vegetable and arable cropping systems (e.g., Meynard et al., 2018; Morel et al., 2020). In our study, we found eighteen coupled innovations implementing crop diversification (Table 3), e.g., by successfully renting or exchanging fields (cluster 5 ) or through the participatory breeding of crops within a cooperative (Cs31). As regards the second point (ii), many scholars pointed out the lack of coordination between the different actors of the agrifood system as a barrier to the transition towards agroecological farming practices (e.g., Boulestreau et al., 2021; Meynard et al., 2017; Schiller et al., 2019). The clusters 1 and 3 are of special interest as they are characterized by functions tackling this barrier, respectively Structuring of a new network and Facilitation of communication between stakeholders (Table 4). Besides, they group innovations involving a variety of actors from the agrifood system (Fig. 2). For instance, the cluster 3 shows eight examples of coupled innovations involving the coordination of stakeholders across the value chain, which support the implementation of agroecological practices (e.g. Cs37, section 3.3). Therefore, our method allows to quickly identify the 
relevant innovation examples, either by the ACP practices (Table 3), by the sociotechnical lever functions (e.g., Structuring of a new network, Table 4) or by the clusters (Fig. 2).

To conclude, in line with design literature and agricultural systems literature, we believe that the five ideotypes and their coupled innovations could serve as 'expansive examples', increasing creative performance in the concept exploration phase, when designing solutions to support agroecological practices in other contexts (Agogué et al., 2013; Hooge et al., 2016; Klerkx et al., 2010; Périnelle et al., 2021; Romera et al., 2020; Salembier et al., 2018). They do not provide pre-defined design pathways for coupled innovation, which must be followed, rather new knowledge that can inspire other design processes in relation to their context.

\subsubsection{Identifying key conditions of success to support coupled innovation design and} niche management in other contexts

Compared to the monographic studies cited above (4.1.1), the contribution of our study is to show and illustrate, for each of the five ideotypes, the general conditions for successful implementation of innovations and the variability of these conditions, which depend on the innovation contexts. It provides insights for other contexts on the key factors to take into account and the barriers to anticipate when designing detailed proposals and implementing similar coupled innovations.

From our results, we drew cross-cutting insights on the key conditions of success for the studied coupled innovations. First, our data showed that human factors are key factors of success in all cases: a shared motivation for and vision of the project among stakeholders, shared trust, active involvement of each partner, good communication, and an ability to make trade-offs. This finding is supported by extensive literature (e.g., Berthet and Hickey, 2018; Cerf et al., 2017; Kilelu et al., 2013; Lucas et al., 2018). Second, involving farmers in coordinated actions initiated by other stakeholders has often been reported to be challenging (as in Berthet and Hickey, 2018), whereas it was found easier when the farmers initiated or were involved in the project at an early stage. Third, organic farming was overrepresented in the first four clusters and not represented in the fifth one. We posit that this overrepresentation is due to the organic farming sector being a pioneer for alternatives both at the farm and the agrifood system level as has already been described in other studies (Boulestreau et al., 2021; Niggli et al., 2015). Regarding Cluster 5, the absence of organic farms is likely due to the distance between organic farms, in a context of a limited area dedicated to organic farming on French territory (7,8\% for fresh vegetables in 2019 , see 2.3$)$. Fourth, intermediaries played a key role in the majority of the coupled innovations we studied, which is in line with an extensive literature on innovation in agricultural systems (e.g., Berthet and Hickey, 2018; Kilelu et al., 2013; Kivimaa et al., 2019; Klerkx et al., 2010; Leeuwis, 2013). 
These conditions for the innovation success concern mainly the good functioning and sustainability of the networks in which the coupled innovations were designed, i.e., orgware and software components of the coupled innovations (Kilelu et al., 2013; Leeuwis, 2013). In line with recent literature on the application of the sustainability transition concepts on agricultural case studies (Bui et al., 2016; Gaitán-Cremaschi et al., 2019; Ollivier et al., 2018), we found that depending on the studied cases, the networks were either (i) part of innovation niches in various stages of development distinct from a regime (e.g., Cs29, in section 3.3.1, showing the development of a small local network around the local supply of banker plants; Cs27, 3.3.4; Cs5, 3.3.5), (ii) embedded in a regime (e.g., Cs23, 3.3.2, showing the work of a network of large actors from the organic regime to enable crop diversification) or (iii) in a hybrid configuration (e.g., Cs37, 3.3.3, bridging niche network around conservation agriculture in gardening and small-scale market gardening with big players of the food industry and retailing). Thus, the study of coupled innovations also helps understand how to develop and maintain niche networks that can support the design of coupled innovations in different contexts (see Berthet et al., 2018).

\subsection{Tracking down coupled innovation: a new methodology}

This is the first cross-cutting study carried out on such a large sample of existing coupled innovations, with a typological approach. In the following sections, we discuss our contribution to the development of a new methodology that produces actionable knowledge on coupled innovations to support the design of coupled innovations in other contexts.

\subsubsection{A methodology complementary to existing ones}

The monograph studies on existing coupled innovations (see 4.1.1) focus on one or a few cases to unveil specific processes in agricultural innovation systems (Berthet and Hickey, 2018; Kernecker et al., 2021; Kilelu et al., 2013; Klerkx et al., 2010; Schiller et al., 2019), innovation niches (Bui et al., 2016) or specific innovation types (Compagnone, 2019; Lucas et al., 2018). On the contrary, 'tracking down coupled innovation' gives an overview of the different innovation types across a large sample of coupled innovations, the different combinations of sociotechnical levers, the function they perform to overcome the barriers to the change in practice, and their (diverse) conditions for a successful implementation. As argued in the previous section, this has the potential to support the design of coupled innovations in other contexts.

In order to analyze the means by which existing coupled innovations overcome the barriers to the change in practices, we introduced the concept of 'sociotechnical levers' (Section 2.1). This concept, applied to our case studies, together with the analytical framework of farming practice determinants (Table 1), supported the identification of a diversity of key functions, which allowed to overcome barriers to the implementation of ACP. This concept intersects others already present in the literature such as the 'functions' of a technological innovation system oriented towards supporting 
innovation (e.g., Knowledge development; Market formation - Schiller et al., 2019). It differs from them as lever functions are fully oriented towards overcoming barriers to change in farming practices within the sociotechnical system. Besides, the designated functions are fulfilled not by the innovation system as a whole but by the coupled innovations that were produced in the innovation system. It then allows capturing the key functions activated by existing coupled innovations to overcome barriers to change, the underlying actions carried out and the conditions for their successful implementation.

The coupled innovations we studied are made up of innovative farming practices at the field and farm level and the STAFS-level innovations fostering their implementation. When 'tracking down innovative cropping systems' focuses on the implementation of innovative farming practices (Périnelle et al., 2021; Salembier et al., 2016; Verret et al., 2020), our method 'tracking down coupled innovation' aims to study the implementation of the practices and the STAFS-level innovations together. The goal is the same for both methods: producing knowledge to support the design of agroecological innovations in other contexts. They also share the same general approach: making a typology of the innovations to produce more generic knowledge (Périnelle et al., 2021; Salembier et al., 2016; Verret et al., 2020). Yet, the scopes differ. This has methodological consequences. For instance, we interviewed a wider range of stakeholders (e.g., marketing firms, inter-branch organization), with a focus on the coordination at STAFS level rather than the technical implementation of the farming practices and their outcomes. When the multi-criteria assessment of cropping systems is a well-developed approach (Dogliotti et al., 2004; Ravier et al., 2015; Salembier et al., 2016), the evaluation of coupled innovations remains an avenue for future research as their complexity (multi-actor, multi-level interactions) makes it difficult to evaluate them effectively. In our study, only a qualitative evaluation by innovation's stakeholders could be attempted and was undermined by the lack of data and hindsight of the interviewees. Ultimately, the two approaches have complementary scopes and applying them jointly would be beneficial. Identifying the innovative farming practices could serve as a starting point to spot technical, organizational or institutional innovation(s) at STAFS level that foster the practice implementation. Besides, it would provide detailed knowledge on the implemented farming practices and an evaluation of coupled innovations' impacts, by providing an evaluation of farming practices' impacts on the agroecosystems.

\subsubsection{Room for improvement}

Our approach could be improved in three areas: (i) the identification of case studies, (ii) the survey of innovation stakeholders, (iii) the interpretation of the results. As regards the first point (i), examples of coupled innovations provided to experts to help them grasp what we are looking for should be 
carefully selected (see 2.2). "Expansive examples" should be favored: examples that are radically novel for the expert, encouraging them to look for a diversity of innovative examples (Agogué et al., 2013). As regards the survey (ii), our approach would benefit from having a greater number of interviews per innovation tracked, beyond the few that we studied in depth. Indeed, some of the data could be missing or biased, due to an asymmetry in the information collected. Nevertheless, we posit that in our study, the potential bias was mostly overcome through the cross-analysis of numerous cases. Finally (iii), the choice of the categories for the supplementary variables needs to be improved, so as to be less sensitive to subjectivity and more reproducible. For example, several barriers or conditions for success can have the same importance or be intertwined, as in the case of the combination of a lack of material resources to transport equipment and a large distance between two farms hindering the sharing of equipment.

\section{Conclusion}

In this study, we designed and applied an original 'tracking down coupled innovation' method to produce actionable knowledge on existing coupled innovations, based on a novel conceptual and analytical framework (2.1, Table 1, Table 2). We extended the definition of 'coupled innovation' to capture the variety of innovations, which are designed across the different components of the agrifood systems and tackle the interconnected barriers to the implementation of agroecological crop protection (ACP). We then introduced the concept of 'sociotechnical lever', and their functions, to seize the means by which coupled innovations overcome the barriers to changes towards ACP. The notion of 'conditions for the implementation of the coupled innovations' complemented our framework to reveal factors of successful implementation and the pitfalls to overcome depending on the innovation context.

We showed that the application of this method to our case study produced resources that can support the design of new coupled innovations in other contexts: (1) the 17 identified functions of the sociotechnical levers; (2) the 5 ideotypes of coupled innovations based on the performed functions, and for each of them, (2a) the variety of coordinated actions performing the functions and (2b) the variety of conditions for the implementation of the innovations. This method complements the existing 'tracking down innovative cropping systems' method, by focusing on the analysis of the orgware, software and hardware components beyond the farm level, which support the implementation of the innovative cropping systems. Extension services, supported by policies, capitalize already more and more on farmers' innovative agroecological cropping systems to design new ones adapted to other contexts. Yet, to overcome the STAFS-level barriers impeding their 
implementation, we recommend combining it with a 'tracking down coupled innovation' method. We hypothesize that it would support the implementation of existing agroecological cropping systems beyond the niches in which they were developed. We then stress two future research avenues: (i) developing methods to adequately combine 'tracking down innovative cropping system' and 'tracking down coupled innovations', and (ii) exploring how the knowledge produced by 'tracking down coupled innovation' can best support the design of coupled innovations in other contexts.

\section{Acknowledgements}

This work was supported by the French Environment and Energy Management Agency (ADEME), ACT department of INRAE, ITAB, the GISPICLeg and UMT SI BIO. We are grateful to all the actors whom we interviewed, and those who helped us to get in contact with actors from new case studies. We also thank Nonta and Liz Carey Libbrecht for their corrections.

\section{References}

Agence Bio, 2020. La consommation bio en hausse en 2019 stimule la production et la structuration des filières françaises: Les chiffres 2019 du secteur bio. https://www.agencebio.org/wp-content/uploads/2020/07/DP-AGENCE-BIO-CHIFFRES2019_def.pdf. Accessed 7 April 2021.

Agogué, M., Kazakçi, A., Hatchuel, A., Le Masson, P., Weil, B., Poirel, N., Cassotti, M., 2013. The Impact of Type of Examples on Originality: Explaining Fixation and Stimulation Effects. J Creat Behav 48, 1-12. 10.1002/jocb.37.

Arthur, W.B., 1989. Competing technologies, increasing returns, and lock-in by historical events. Econ J 99, 116-131. 10.2307/2234208.

Baros, C., 2021. (Mé)Connaissance, perception de attentes des consommateurs en matière d'agroécologie, 1 February 2021.

Belmin, R., Meynard, J.-M., Julhia, L., Casabianca, F., 2018. Sociotechnical controversies as warning signs for niche governance. Agron Sustain Dev 38, 32. 10.1007/s13593-0180521-7.

Bernard de Raymond, A., 2013. En toute saison. Le marché des fruits et légumes en France. Presses universitaires de Rennes.

Berthet, E.T., Hickey, G.M., 2018. Organizing collective innovation in support of sustainable agro-ecosystems: The role of network management. Agric Syst 165, 44-54. 10.1016/j.agsy.2018.05.016.

Berthet, E.T., Hickey, G.M., Klerkx, L., 2018. Opening design and innovation processes in agriculture: Insights from design and management sciences and future directions. Agric Syst 165, 111-115. 10.1016/j.agsy.2018.06.004.

Boulestreau, Y., Casagrande, M., Navarrete, M., 2021. Analyzing barriers and levers for practice change: a new framework applied to vegetables' soil pest management. Agron Sustain Dev 41, 44. 10.1007/s13593-021-00700-4.

Brun, J., Jeuffroy, M.-H., Pénicaud, C., Cerf, M., Meynard, J.-M., 2021. Designing a research agenda for coupled innovation towards sustainable agrifood systems. Agric Syst 191, 1031 43. 10.1016/j.agsy.2021.103143. 
Bui, S., Cardona, A., Lamine, C., Cerf, M., 2016. Sustainability transitions: Insights on processes of niche-regime interaction and regime reconfiguration in agri-food systems. $\mathrm{J}$ Rural Stud 48, 92-103. 10.1016/j.jrurstud.2016.10.003.

Cerf, M., Le Bail, Lusson, J.M., Omon, B., 2017. Contrasting intermediation practices in various advisory service networks in the case of the French Ecophyto plan. The Journal of Agricultural Education and Extension 23, 231-244. 10.1080/1389224X.2017.1320641.

Chantre, E., Cardona, A., 2014. Trajectories of french field crop farmers moving toward sustainable farming practices: Change, learning, and links with the advisory services. Agroecol Sustain Food Syst 38, 573-602. 10.1080/21683565.2013.876483.

Clément, C., Perrin, C., Soulard, C.-T., 2019. Les arrangements pour l'accès au foncier agricole périurbain. Développement durable \& territoires 10. 10.4000/developpementdurable.15933.

Compagnone, C., 2019. Sociologie des changements de pratiques en agriculture: L'apport de l'étude des réseaux de dialogues entre pairs. Quae.

Cowan, R., Gunby, P., 1996. Sprayed to death: Path dependence, lock-in and pest control strategies. Econ J 106, 521-542. 10.2307/2235561.

Deguine, J.-P., Gloanec, C., Laurent, P., Ratnadass, A., Aubertot, J.-N. (Eds.), 2016. Protection agroécologique des cultures. Éditions Quae, Versailles, $1287 \mathrm{pp}$.

Deguine, J.-P., Ratnadass, A., Robin, M.-H., Sarthou, J.-P., Aubertot, J.-N., 2020. Agroecological crop protection: Definition. https://dicoagroecologie.fr/en/encyclopedia/agroecological-crop-protection/. Accessed 14 January 2021.

Della Rossa, P., Le Bail, M., Mottes, C., Jannoyer, M., Cattan, P., 2020. Innovations developed within supply chains hinder territorial ecological transition: The case of a watershed in Martinique. Agron Sustain Dev 40, 32. 10.1007/s13593-020-0613-z.

Dogliotti, S., Rossing, W.A.H., van Ittersum, M.K., 2004. Systematic design and evaluation of crop rotations enhancing soil conservation, soil fertility and farm income: A case study for vegetable farms in South Uruguay. Agric Syst 80, 277-302. 10.1016/j.agsy.2003.08.001.

Eurostat, 2021. Agri-environmental indicator - consumption of pesticides. https://ec.europa.eu/eurostat/statistics-explained/index.php?title=Agrienvironmental_indicator_-_consumption_of_pesticides\#Key_messages. Accessed 30 July 2021.

Faure, G., Chiffoleau, Y., GOULET, F., Temple, L., Touzard, J.-M. (Eds.), 2018. Innovation et développement dans les systèmes agricoles et alimentaires. Quae, Versailles, 263 pp.

Gaitán-Cremaschi, D., Klerkx, L., Duncan, J., Trienekens, J.H., Huenchuleo, C., Dogliotti, S., Contesse, M.E., Benitez-Altuna, F.J., Rossing, W.A.H., 2020. Sustainability transition pathways through ecological intensification: An assessment of vegetable food systems in Chile. Int J Agric Sustain 18, 131-150. 10.1080/14735903.2020.1722561.

Gaitán-Cremaschi, D., Klerkx, L., Duncan, J., Trienekens, J.H., Huenchuleo, C., Dogliotti, S., Contesse, M.E., Rossing, W.A.H., 2019. Characterizing diversity of food systems in view of sustainability transitions. A review. Agron. Sustain. Dev. 39, 1. 10.1007/s13593-0180550-2.

Gamliel, A., van Bruggen, A.H.C., 2016. Maintaining soil health for crop production in organic greenhouses. Sci Hortic 208, 120-130. 10.1016/j.scienta.2015.12.030.

Geels, F.W., 2002. Technological transitions as evolutionary reconfiguration processes: A multi-level perspective and a case-study. Res Policy 31, 1257-1274. 10.1016/S00487333(02)00062-8. 
Geels, F.W., 2011. The multi-level perspective on sustainability transitions: Responses to seven criticisms. Environmental Innovation and Societal Transitions 1, 24-40. 10.1016/j.eist.2011.02.002.

Geels, F.W., Schot, J., 2007. Typology of sociotechnical transition pathways. Res Policy 36, 399-417. 10.1016/j.respol.2007.01.003.

Girard, N., 2015. Knowledge at the boundary between science and society: A review of the use of farmers' knowledge in agricultural development. Journal of Knowledge Management 19, 949-967. 10.1108/JKM-02-2015-0049.

HLPE, 2014. Food losses and waste in the context of sustainable food systems. A report by the High Level Panel of Experts on Food Security and Nutrition of the Committee on World Food Security. http://www.fao.org/3/a-i3901e.pdf. Accessed 10 April 2020.

Hooge, S., Béjean, M., Arnoux, F., 2016. Organising for radical innovation: The benefits of the interplay between cognitive and organisational processes in KCP workshops. Int. J. Innov. Mgt. 20, 1640004. 10.1142/S1363919616400041.

Kernecker, M., Seufert, V., Chapman, M., 2021. Farmer-centered ecological intensification: Using innovation characteristics to identify barriers and opportunities for a transition of agroecosystems towards sustainability. Agricultural Systems 191, 103142. 10.1016/j.agsy.2021.103142.

Kilelu, C.W., Klerkx, L., Leeuwis, C., 2013. Unravelling the role of innovation platforms in supporting co-evolution of innovation: Contributions and tensions in a smallholder dairy development programme. Agric Syst 118, 65-77. 10.1016/j.agsy.2013.03.003.

Kivimaa, P., Hyysalo, S., Boon, W., Klerkx, L., Martiskainen, M., Schot, J., 2019. Passing the baton: How intermediaries advance sustainability transitions in different phases. Environmental Innovation and Societal Transitions 31, 110-125. 10.1016/j.eist.2019.01.001.

Klerkx, L., Aarts, N., Leeuwis, C., 2010. Adaptive management in agricultural innovation systems: The interactions between innovation networks and their environment. Agric Syst 103, 390-400. 10.1016/j.agsy.2010.03.012.

Klerkx, L., Begemann, S., 2020. Supporting food systems transformation: The what, why, who, where and how of mission-oriented agricultural innovation systems. Agric Syst 184, 102901. 10.1016/j.agsy.2020.102901.

Lambrecht, E., Kühne, B., Gellynck, X., 2014. How Do Innovation Partners Differ with Respect to Innovation Type and Stage in the Innovation Journey of Farmers? The International Journal of Entrepreneurship and Innovation 15, 191-203. 10.5367/ijei.2014.0155.

Lamers, D., Schut, M., Klerkx, L., van Asten, P., 2017. Compositional dynamics of multilevel innovation platforms in agricultural research for development. Science and Public Policy 44, 739-752. 10.1093/scipol/scx009.

Lê, S., Josse, J., Husson, F., 2008. FactoMineR: An R package for multivariate analysis. Journal of statistical software 25, 1-18.

Leeuwis, C., 2013. Coupled Performance and Change in the Making. Wageningen University. Unaugural lecture, 6 June 2013, Wageningen.

Lefèvre, A., Perrin, B., Lesur-Dumoulin, C., Salembier, C., Navarrete, M., 2020. Challenges of complying with both food value chain specifications and agroecology principles in vegetable crop protection. Agricultural Systems 185, 102953. 10.1016/j.agsy.2020.102953.

Lucas, V., Gasselin, P., van der Ploeg, J.D., 2018. Local inter-farm cooperation: A hidden potential for the agroecological transition in northern agricultures. Agroecol Sustain Food Syst 43, 145-179. 10.1080/21683565.2018.1509168. 
Magrini, M.-B., Duru, M., 2014. Dynamics of innovation in the nutrition of dairy cattle: An assessment of the diffusion process of the'Bleu-Blanc-Coeur'scheme and its repercussions. Fourrages, 79-90.

Mawois, M., Vidal, A., Revoyron, E., Casagrande, M., Jeuffroy, M.-H., Le Bail, M., 2019. Transition to legume-based farming systems requires stable outlets, learning, and peernetworking. Agron Sustain Dev 39, 19. 10.1007/s13593-019-0559-1.

Meynard, J.-M., Charrier, F., Le Bail, M., Magrini, M.-B., Charlier, A., Messéan, A., 2018. Socio-technical lock-in hinders crop diversification in France. Agron Sustain Dev 38, 54. 10.1007/s13593-018-0535-1.

Meynard, J.-M., Jeuffroy, M.-H., Le Bail, M., Lefèvre, A., Magrini, M.-B., Michon, C., 2017. Designing coupled innovations for the sustainability transition of agrifood systems. Agric Syst 157, 330-339. 10.1016/j.agsy.2016.08.002.

Ministère de l'agriculture et de l'alimentation, 2020. Note de duivi 2018-2019 du plan Ecophyto, 52 pp. https://ecophytopic.fr/sites/default/files/2020-02/ecophyto-note-de-suivi2018-2019-vdef-compresse.pdf. Accessed 30 July 2021.

Montes de Oca Munguia, O., Pannell, D.J., Llewellyn, R., Stahlmann-Brown, P., 2021. Adoption pathway analysis: Representing the dynamics and diversity of adoption for agricultural practices. Agricultural Systems 191, 103173. 10.1016/j.agsy.2021.103173.

Morel, K., Revoyron, E., San Cristobal, M., Baret, P.V., 2020. Innovating within or outside dominant food systems? Different challenges for contrasting crop diversification strategies in Europe. PloS one 15, e0229910. 10.1371/journal.pone.0229910.

Niggli, U., Plagge, J., Reese, S., Fertl, T., Schmid, O., Brändli, U., Bärtschi, D., Pöpsel, G., Hermanowski, R., Hohenester, H., 2015. Towards modern sustainable agriculture with organic farming as the leading model. A discussion document on Organic 3, 36.

Ollivier, G., Magda, D., Mazé, A., Plumecocq, G., Lamine, C., 2018. Agroecological transitions: What can sustainability transition frameworks teach us? An ontological and empirical analysis. Ecol Soc 23, 5. 10.5751/ES-09952-230205.

Palm, C., Blanco-Canqui, H., DeClerck, F., Gatere, L., Grace, P., 2014. Conservation agriculture and ecosystem services: An overview. Agriculture, Ecosystems \& Environment 187, 87-105. 10.1016/j.agee.2013.10.010.

Périnelle, A., Meynard, J.-M., Scopel, E., 2021. Combining on-farm innovation tracking and participatory prototyping trials to develop legume-based cropping systems in West Africa. Agricultural Systems 187, 102978. 10.1016/j.agsy.2020.102978.

Peyras, C.-L., 2019. Analyse des innovations organisationnelles permettant la gestion des bioagresseurs des légumes à l'échelle des territoires. option Production Végétale Durable. Montpellier Supagro, $85 \mathrm{pp}$.

Pigford, A.-A.E., Hickey, G.M., Klerkx, L., 2018. Beyond agricultural innovation systems?: Exploring an agricultural innovation ecosystems approach for niche design and development in sustainability transitions. Agric Syst 164, 116-121. 10.1016/j.agsy.2018.04.007.

Plumecocq, G., Debril, T., Duru, M., Magrini, M.-B., Sarthou, J.P., Therond, O., 2018. The plurality of values in sustainable agriculture models: Diverse lock-in and coevolution patterns. Ecol Soc 23, 21. 10.5751/ES-09881-230121.

Probst, L., Adoukonou, A., Amankwah, A., Diarra, A., Vogl, C.R., Hauser, M., 2012. Understanding change at farm level to facilitate innovation towards sustainable plant protection: A case study at cabbage production sites in urban West Africa. International Journal of Agricultural Sustainability 10, 40-60. 10.1080/14735903.2012.649589.

Ravier, C., Prost, L., Jeuffroy, M.-H., Wezel, A., Paravano, L., Reau, R., 2015. Multi-criteria and multi-stakeholder assessment of cropping systems for a result-oriented water quality 
preservation action programme. Land Use Policy 42, 131-140. 10.1016/j.landusepol.2014.07.006.

Rip, A., Kemp, R., 1998. Technological change, in: Rayner, S., Malone, E.L. (Eds.), Human choice and climate change. Volume 2: Resources and technology, vol. 2. Battelle Press, Columbus, OH (United States), pp. 327-399.

Romera, A.J., Bos, A.P., Neal, M., Eastwood, C.R., Chapman, D., McWilliam, W., Royds, D., O'Connor, C., Brookes, R., Connolly, J., Hall, P., Clinton, P.W., 2020. Designing future dairy systems for New Zealand using reflexive interactive design. Agric Syst 181, 102818. 10.1016/j.agsy.2020.102818.

Salembier, C., Elverdin, J.H., Meynard, J.-M., 2016. Tracking on-farm innovations to unearth alternatives to the dominant soybean-based system in the Argentinean Pampa. Agron Sustain Dev 36, 1. 10.1007/s13593-015-0343-9.

Salembier, C., Segrestin, B., Berthet, E., Weil, B., Meynard, J.-M., 2018. Genealogy of design reasoning in agronomy: Lessons for supporting the design of agricultural systems. Agric Syst 164, 277-290. 10.1016/j.agsy.2018.05.005.

Salembier, C., Segrestin, B., Sinoir, N., Templier, J., Weil, B., Meynard, J.-M., 2020. Design of equipment for agroecology: Coupled innovation processes led by farmer-designers. Agric Syst 183, 102856. 10.1016/j.agsy.2020.102856.

Schiller, K., Godek, W., Klerkx, L., Poortvliet, P.M., 2020. Nicaragua's agroecological transition: Transformation or reconfiguration of the agri-food regime? Agroecol Sustain Food Syst 44, 611-628. 10.1080/21683565.2019.1667939.

Schiller, K.J.F., Klerkx, L., Poortvliet, P.M., Godek, W., 2019. Exploring barriers to the agroecological transition in Nicaragua: A Technological Innovation Systems Approach. Agroecol Sustain Food Syst 10, 1-45. 10.1080/21683565.2019.1602097.

Schut, M., Rodenburg, J., Klerkx, L., Kayeke, J., van Ast, A., Bastiaans, L., 2015. RAAIS: Rapid Appraisal of Agricultural Innovation Systems (Part II). Integrated analysis of parasitic weed problems in rice in Tanzania. Agric Syst 132, 12-24. 10.1016/j.agsy.2014.09.004.

Soulard, C.-T., 2014. Les agricultures nomades, une caractéristique du périurbain. Pour 224, 151. 10.3917/pour.224.0151.

Tilman, D., Cassman, K.G., Matson, P.A., Naylor, R., Polasky, S., 2002. Agricultural sustainability and intensive production practices. Nat 418, 671.

Vanloqueren, G., Baret, P.V., 2009. How agricultural research systems shape a technological regime that develops genetic engineering but locks out agroecological innovations. Res Policy 38, 971-983. 10.1016/j.respol.2009.02.008.

Verret, V., Pelzer, E., Bedoussac, L., Jeuffroy, M.-H., 2020. Tracking on-farm innovative practices to support crop mixture design: The case of annual mixtures including a legume crop. European Journal of Agronomy 115, 126018. 10.1016/j.eja.2020.126018.

Wezel, A., Casagrande, M., Celette, F., Vian, J.-F., Ferrer, A., Peigné, J., 2014. Agroecological practices for sustainable agriculture. A review. Agron Sustain Dev 34, 120. 10.1007/s13593-013-0180-7. 